RADOVI

Zavoda za znanstveni rad HAZU Varaždin

ANA KANIŠKI

Varaždin

ana.kaniski@gmail.com
UDK 930Horvat, R.(497.523Varaždin)

Izvorni znanstveni članak Original Scientific Paper

Primljeno: 13. 07. 2018.

Prihvaćeno: 10. 10. 2018.

DOI: https://dx.doi.org/10.21857/mnlqgc060y

\title{
RUDOLF HORVAT O SVOJEM RUKOPISU POVIJEST GRADA VARAŽDINA
}

»Kada se latih prikupljanja izvora za povijest grada Varaždina, bilo mi je 36 godina. Sada sam starac od 60 godina. Razumjet ćete dakle moju vruću želju, da povijest grada Varaždina bude štampana godine 1934. S moje strane ne će tom biti nikakove zapreke, ako mi dragi Bog podijeli život $i$ zdravlje. Ja sam naime glavni posao već dovršio, te sada pišem djelo na čisto, da bude sposobno za štampu«. Rudolf Horvat, pismo 24. kolovoza 1933. ${ }^{1}$

Najopsežnije i sigurno najcitiranije djelo o povijesti »grada baroka«, epitet je kojim se nesumnjivo može opisati Povijest grada Varaždina renomiranog hrvatskog povjesničara Rudolfa Horvata (Koprivnica, 14. ožujka 1873. - Zagreb, 25. svibnja 1947.). Njegovim se tiskom namjeravalo dostojno obilježiti proslavu jubileja sedamstogodišnjice grada Varaždina, za što je onodobno Poglavarstvo grada Varaždina povjesničara angažiralo u travnju 1909. godine. Međutim, tiskano je tek 1993. godine. Godine 2017. navršilo se sedam desetljeća od piščeve smrti, a 2018. godine 125 godina od njegova rođenja i četvrt stoljeća od tiskanja knjige. Osim uz dosadašnjih historiografskih i izvora iz tadašnjih varaždinskih tjednih novina, na temelju sačuvanih arhivskih dokumenata iz Hrvatskog državnog arhiva i Državnog arhiva u Varaždinu - iz osobnog fonda Rudolfa Horvata, iz sačuvane korespondencije između povjesničara i Gradskog poglavarstva Varaždin pri čemu se ističu četiri sačuvana povjesničareva rukopisna pisma, te točaka

Državni arhiv u Varaždinu (dalje: DAVŽ), [0649] Gradsko poglavarstvo Varaždin - Varaždin (1918.-1941.), Korespondencija Gradskog poglavarstva Varaždin i Rudolfa Horvata o knjizi »Povijest grada Varaždina« 1933.-1939., (dalje: [0649] GPV, Korespondencija GPV i RH): pismo Rudolfa Horvata, 24. kolovoza 1933., 13935/1933. 
sjednica skupština gradske vlasti iz prve polovice XX. stoljeća, autorica u radu, osim što prvi puta donosi prijepise najvažnijih spisa, prikazuje okolnosti i tijek nastanka djela. Također, zaključuje da dva sačuvana povjesničareva rukopisa u Gradskom muzeju Varaždin čine jedinstvenu Povijest grada Varaždina koji je R. Horvat predavao u dijelovima, izravno osobnim dolaskom ili putem gradonačelnika Novakovića ili dragog prijatelja, u pet navrata, u razdoblju od 1934. do 1939. godine. Njegov je I. dio, opća ili politička povijest tiskan tek 1993. godine, a tematski II. dio, Kulturna povijest grada Varaždina, sa zasebnim poglavljima, ostao je neobjavljen.

\section{DOSADAŠNJA ISTRAŽIVANJA}

Između desetak autora koji su se pišući o različitim temama vezanih za sjeverozapadnu Hrvatsku, Varaždin i varaždinski kraj dotakli i tiskane knjige Rudolfa Horvata Povijest grada Varaždina, u okviru ovog rada, u ovom poglavlju se donosi kratki pregled dosadašnjih istraživanja vezanih za sam njezin nastanak, to jest, ne o njezinom sadržaju, i o njezinom autoru.

U predgovoru knjige Zlatka Tanodija, tadašnji gradski vijećnik Mirko Hikec [1942.], uz postojeće (ne)objavljene knjige o varaždinskoj povijesti L. Ebnera, I. Kukuljevića-Sakcinskoga, J. Jankovića, K. Filića i L. Pihlera, izdvojio je rukopis Povijest grada Varaždina navevši da je na inicijativu gradske vlasti, započeto još prije 30 godina, ali se to - »nedavno dovršeno novo vrlo obsežno djelo« nije moglo tiskati zbog tadašnjih ratnih prilika. ${ }^{2}$ Nekadašnja ravnateljica Gradskog muzeja Varaždin, Jasna Tomičić [1981.] je u članku Kako (ni)su Varaždinci proslavili 700. godišnjicu, na temelju novinskih naslova iz prvog desetljeća XX. stoljeća, sažeto prikazala ideje, želje, nastojanja, provedbu programa i odgodu proslave jubilej kada je Varaždin dobio povlasticu slobodnog i kraljevskog grada (120.). Usprkos »oštrih napada novinara « jer se proslava nije održala, navela je da je Horvatov rukopis negdje iza 1936. godine zalutao u ladice muzeja i izrazila misao da njegov tisak planira povodom obilježavanja 800 . godina od prvog spomena imena grada Varaždina (1981.). ${ }^{3}$ Skupština Samoupravne interesne zajednice općine Varaždin odlukom je Republičkom SIZ kulture u travnju 1985. godine u književno-izdavačkoj djelatnosti, previdjela i tisak rukopisa. ${ }^{4} \mathrm{U}$ međuvremenu, rukopisom su

2 Mirko HIKEC, »Predgovor«, Poviestni spomenici slobodnog i kraljevskog grada Varaždina. Svezak prvi. Zbornik izprava 1209.-1526. iz arhiva Grada Varaždina., Svobodina »Narodna tiskara«, Obćina slob. i kr. grada Varaždina, Varaždin, 1942., VII.

3 Jasna TOMIČIĆ, »Kako (ni)su Varaždinski proslavili 700. godišnjicu«, Varaždinske vijesti, 5. ožujka 1981., br. 9, 8 .

4 (ž), »Prijedlog kulturnih potreba RSIZ-u«, Varaždinske vijesti, 27. lipnja 1985., br. $2110,7$. 
se koristili i mnogi novinari u pisanju svojih članaka. Obilježavajući 120 godina od povjesničareva rođenja, Denis Peričić [1993.] je oštrim člankom Zanijekani povjesničar izrazio želju da se konačno tiska rukopis koji su mnogi stručni autori »obilato koristili, citirali i među vrelima uredno navodili `nepostojeće < djelo, djelo povijesnika kojega je donedavna službena povijesna znanost - zanijekala «. ${ }^{5}$ Izvršno vijeće Skupštine općine Varaždin prihvatilo je molbu Zavoda za znanstveni rad HAZU u Varaždinu da osigura sredstva potrebna za tiskanje rukopisa i namijenilo mu 30 tisuća DEM. ${ }^{6}$ Povodom obilježavanja Dana grada Varaždina 6. prosinca 1993. godine akademik Andre Mohorovičić predstavio je iščekivanu tiskanu Povijest grada Varaždina. ${ }^{7}$

U predgovoru tiskanoj knjizi, koja sadrži i popis Horvatovih radova o povijesti grada Varaždina i varaždinskog kraja, Miroslav Kurelac [1993.] je dao kratki prikaz ugovaranja pisanja rukopisa: ideju su bili potaknuli varaždinski gradonačelnik Ljudevit Jurinac, veliki župan Varaždinske županije Janko pl. Jelačić-Bužimski i hrvatski ban Pavao Rauch, Poglavarstvo grada Varaždina ju je potvrdilo na sjednici 28. travnja 1909. godine, zastupnici su odlučili da će Horvatu isplatiti predujam (300 kruna), ishoditi mu jednogodišnji dopust i smanjiti nastavne sate u zagrebačkoj gimnaziji i dodijeliti ga na rad u tadašnji Kraljevski hrvatsko-slavonsko-dalmatinski Zemaljski arhiv u Zagrebu. Horvat je prikupljao i obrađivao obilnu arhivsku građu, da bi u međuvremenu objavljene crtice o povijesti grada Varaždina, objedinio studijom Varaždin koncem 16. vijeka. ${ }^{8}$ Kurelac je smatrao da je Horvat rukopis završio 1912. godine. ${ }^{9}$

Stavljajući po strani tekstove o Horvatu koji su objavili njegovi istovremenici, o njegovom životu i djelu pisali su autori iz različitih znanstvenih područja najčešće u okviru predgovorā pretisaka Horvatovih radova ili, rjeđe, posthumno objavljenih djela osvrćući se na njegov život i djelo dajući kritička mišljenja o njegovim radovima (obuhvaćenost tematike, način korištenja izvorā i znanstvenog aparata). U predgovoru pretiska knjige Hrvatska na mučilištu, Hrvoje Matković [1992.] je među Horvatovim radovima o hrvatskim krajevima i gradovima, izdvojio studiju Varaždin koncem 16. vijeka, te rukopis Politička i kulturna povijest grada Varaždina. ${ }^{10}$ Prvu Horvatovu bibliografiju dala je Mira Kolar-Dimitrijević

Denis PERIČIĆ, »Zanijekani povjesničar«, Varaždinske vijesti, 17. ožujka 1993., br. 2513, 9.

A. KLARIĆ, »Povijest grada Varaždina«, Varaždinske vijesti, 31. ožujka 1993., br. 2515, 7.

T. ŠUMIGA, »Grad Kulture, i otvorena srca.«, Varaždinske vijesti, 8. prosinca 1993., br. 2552, 3.

Rudolf HORVAT, Varaždin koncem 16. vijeka, Tisak Kraljevske zemaljske tiskare, Zagreb, 1912.

Miroslav KURELAC, Predgovor, u: Rudolf HORVAT, Povijest grada Varaždina, ur. Andre Mohorovičić, Varaždin, Zavod za znanstveni rad HAZU Varaždin i Grad Varaždin, 1993., IX-XI.; bibliografija, 525-542.

10 Hrvoje MATKOVIĆ, »Predgovor«, Rudolf HORVAT, Hrvatska na mučilištu, Školska knjiga, Zagreb, 1992. [1942.], VIII-IX. 
[1988.] u pretisku knjige Poviest slob. i kr. grada Koprivnice. ${ }^{11}$ Pretisak knjigā Slavonija I i II Kolar-Dimitrijević [1994.] je upotpunila bibliografijom koja se odnosi na taj kraj i pregledom na Horvatovu djelatnost u tom kraju. ${ }^{12} \mathrm{U}$ godišnjacima Podravski zbornik Kolar-Dimitrijević [1993.-1994.] pisala je o Horvatovom radu u Kopivničkoj Podravini, a Dražen Ernečić [1997.] objavio proslov dvama Horvatovim radovima. ${ }^{13}$

Obilježavajući 50. godišnjicu Horvatove smrti, Hrvatsko povijesno društvo iz Koprivnice, Družba »Braća Hrvatskog Zmaja« i Muzej grada Koprivnice su pod pokroviteljstvom koprivničke gradske vlasti 3. studenog1997. u gradskoj vijećnici priredili znanstveni skup o Horvatovu životu i djelu. Veliki meštar Družbe »Braće Hrvatskog Zmaja « Juraj Kolarić tada je pred zgradom koprivničkog muzeja - rodne kuće Rudolfa Horvata, otkrio spomen-ploču posvećenu Horvatu, dar časopisa Hrvatski zemljopis. ${ }^{14}$ Radovi izlagača na tom skupu okupljeni su u zborniku Dr. Rudolf Horvat - život i djelo: u povodu 50. obljetnice smrti (1947.-1997.) i 125. obljetnice rođenja (1873-1998.). Uz uvodni pregled i bibliografiju radova R. Horvata, glavnina radova govori o Horvatovoj svestranom radu: njegovim radovima o Koprivnici i Podravini, vezama s Koprivnicom, političkom radu, važnosti Horvata u historiografiji Hrvatske i grada Zagreba, njegovom doprinosu etnografiji i razvoju grana hrvatske geografije, te Horvatovoj knjizi Hrvatska na mučilištu (1942.) i supruzi Jelisavi. ${ }^{15} \mathrm{U}$ tom zborniku, pišući o Horvatu kao crkvenom povjesničaru, oslonivši se na »svjedočanstvo« Mirka Hikeca da je Horvat glavninu rukopisa Povijest grada Varaždina dovršio oko 1912. godine i da se » taj rad protegao dulje«, Juraj Kolarić [1998.] je naveo da se Horvat rukopisu mogao posvetiti nakon prisilnog umirovljenja 1932. godine. ${ }^{16} \mathrm{U}$ pretisku Horvatove monografije o Koprivnici objavljeni su bibliografija Horvatovih radova i osvrt

11 Mira KOLAR-DIMITRIJEVIĆ, »Bibliografija radova dra Rudolfa Horvata 1894-1945«, Rudolf HORVAT, Poviest slob. $i$ kr. grada Koprivnice, MAG Agencija za marketing, dizajn i grafičke usluge, Koprivnica, 1988., I-XXVIII.

12 Mira KOLAR-DIMITRIJEVIĆ, »Političko-kulturna djelatnost Rudolfa Horvata u Slavoniji«, Rudolf HORVAT, Slavonija I i II, Slavonska naklada »Privlačića«, Vinkovci, 1994., 273-294.

13 Mira KOLAR-DIMITRIJEVIĆ, »Povjesničar Rudolf Horvat i Koprivnička Podravina«, Podravski zbornik, Muzej grada Koprivnice, ur. Franjo Horvatić, Koprivnica, br. 19-20, 1993.-1994., 29-42.; Dražen ERNEČIĆ, »Uvodno slovo«, Podravski zbornik, Muzej grada Koprivnice, ur. Hrvoje Petrić, Koprivnica, br. 23, 1997., 9-10.

14 D. PERIČIĆ, »Skup o Rudolfu Horvatu«, Varaždinske vijesti, 26. studenog 1997., br. 2759, 12.

15 Dr. Rudolf Horvat -život i djelo: u povodu 50. obljetnice smrti (1947.-1997.) i 125. obljetnice rođenja (18731998.): zbornik referata podnijetih na Znanstvenom skupu Dr. Rudolf Horvat - život i djelo, održanog u Koprionici 1997. godine, Hrvatsko povijesno društvo, Družba »Braća Hrvatskog Zmaja«, Nakladna kuća Dr. Feletar, ur. Dragutin Feletar (dalje: Dr. Rudolf Horvat - život i djelo), Koprivnica, 1998.

16 Juraj KOLARIĆ, »Rudolf Horvat kao crkveni povjesničar«, Dr. Rudolf Horvat - život i djelo, Koprivnica, 1998., 30-38. 
Dražena Ernečića [2003.]. ${ }^{17}$ Navevši da je Horvat u svojih 1200 radova obrađivao povijest krajeva, gradova i osoba, teme iz starije i novije političke gospodarske i kulturne povijesti, Kolar-Dimitrijević [2003.] je izdvojila Varaždin koncem 16. vijeka i tiskanu Povijest grada Varaždina. ${ }^{18}$

U recentnoj historiografiji grada Varaždina i varaždinskoj okolici, petero povjesničara je obrazložilo važnost Horvatove knjige. Vladimir Huzjan i Ivan Obadić [2012.] smatrali su je najobuhvatnijim djelom o povijesti grada Varaždina koje se manjim dijelom dotiče i XX. stoljeća obrazloživši: »Iako je djelo nastalo prije više od jednog stoljeća i ne odgovara standardima suvremene historiografije, Horvat je do danas jedan od najcitiranijih autora o povijesti Varaždina.«, jer je djelo pisano na temelju opširne arhivske građe. ${ }^{19}$ Hrvoje Petrić i Sonja Poljak [2012.] istaknuli su da se u toj »iscrpnoj« knjizi nalazi preko 40\% građe vezano za rani novi vijek. ${ }^{20}$ Stavljajući je uz bok radovima nastalim do 1918. godine, Spomenka Težak [2012.] je smatrala da je Horvat »posao« na rukopisu u najvećoj mjeri obavio do 1912. godine «. ${ }^{21}$ Pišući o političkim zbivanjima u Varaždinu u zadnjim mjesecima Kraljevine Jugoslavije i prvim mjesecima NDH, Vladimir Huzjan [2012.] je naveo da se rukopis nalazio među spisima i kulturnopovijesnim predmetima koji su predani pri promjeni gradske vlasti u travnju 1941. godine. ${ }^{22} \mathrm{U}$ knjizi Varaždin i vojska u međuratnom razdoblju (1918.-1941.), Huzjan [2017.] je naveo da je Horvatov rukopis nastajao u vrijeme od proglašenja Oktroiranog ustava do sredine 1935. godine, što je temeljio na prijepisu Horvatova pisma gradskoj vlasti 24. kolovoza 1933. godine: Kada se latih prikupljanja izvora za povijest grada Varaždina, bilo mi je 30 godina. Sada sam starac od 60 godine, a koji je ostao neobjavljen.23

17 Mira KOLAR-DIMITRIJEVIĆ, »Dr. Rudolf Horvat i Hrvatska«, Rudolf HORVAT, Poviest slob. i kr. grada Koprivnice, Ogranak Matice hrvatske, Koprivnica, 2003. [1943.], 291-298.; Dražen ERNEČIĆ, »Dr. Rudolf Horvat i Koprivnica«, Rudolf HORVAT, Poviest slob. i kr. grada Koprivnice, Ogranak Matice hrvatske, Koprivnica, 2003. [1943.], 299-319.

18 »Horvat, Rudolf«, Hrvatski biografski leksikon, ur. Trpimir Macan, Zagreb, 2002., 657-658.

19 Vladimir HUZJAN i Ivan OBADIĆ, »Historiografija varaždinskog kraja u 20. stoljeću«, Historia varasdiensis: časopis za varaždinsku povjesnicu, Društvo povjesničara grada Varaždina i Varaždinske županije, gl. ur. Hrvoje Petrić i Ivan Obadić (dalje: Historia varasdiensis), Varaždin, br. 2, 2012., 62-63.

20 Hrvoje PETRIĆ i Sonja POLJAK, »O historiografiji Varaždina u ranom novom vijeku (16.-18. stoljeće)«, Historia varasdiensis, Varaždin, br. 2, 2012., 13.

21 Spomenka TEŽAK, »Pregled historiografije o gradu Varaždinu u 19. stoljeću«, Historia varasdiensis, Varaždin, br. 2, 2012., 27.

22 Vladimir HUZJAN, »Varaždin u zadnjim mjesecima Kraljevine Jugoslavije i prvim mjesecima Nezavisne Države Hrvatske«, Radovi zavoda za znanstveni rad HAZU Varaždin, HAZU, gl. ur. Stjepan Damjanović, Zagreb - Varaždin, br. 23, 2012., 370.

23 Vladimir HUZJAN, Varaždin i vojska u međuratnom razdoblju (1918.-1941.), Zavod za znanstveni rad Varaždin HAZU, Varaždin, 2017., 121. Ana Kaniški zahvaljuje autoru što ju je, tijekom njezina istraživanja za ovaj rad, uputio na citat u njegovoj knjizi, tada u pripremi za tisak. 


\section{IZ ŽIVOTA RUDOLFA HORVATA I VEZE S VARAŽDINOM}

Najdetaljnija saznanja o Horvatovom znanstvenom, stručnom i popularnom radu na polju povijesti i njegovoj aktivnosti u politici i kulturi, djelovanju u sklopu raznih društava dala je Mira Kolar-Dimitrijević [1998.]. ${ }^{24}$ Završivši pučku školu u rodnom gradu, Andrija Horvat je sina upisao u gornjogradsku gimnaziju u Zagrebu, ali zbog nemogućnosti plaćanja školarine 1887. godine prebacio ga je na varaždinsku franjevačku gimnaziju gdje je četrnaestogodišnji Rudolf pohađao peti i šesti razred..$^{25}$ Školovanje je nastavio u Zagrebu, u nadbiskupskom sjemeništu, maturirao je 1892. godine na gornjogradskoj gimnaziji, pa upisao studij povijesti i zemljopisa na Mudroslovnom fakultetu. Profesorski ispit položio je 1897., a doktorski rad 1898. godine. Radio je kao profesor povijesti na velikim i realnim gimnazijama i trgovačkim školama u Osijeku (1896.-1901.), Zemunu (1901.-1902.) i Petrinji (1902.-1907.). Autorica piše da je u Petrinji Horvat »shvatio važnost pisanja povijesti pojedinih gradova« kada je objavio i Poviest Medjumurja u varaždinskim tjednim novinama Naše pravice i kao samostalnu knjigu (1907.) zaslugom varaždinskog gradonačelnika Pere Magdića. Njom je na sebe svratio pažnju hrvatskog bana Pavla Raucha koji je nakon tucet molbi prihvatio povjesničarevu želju za premještajem u Zagreb. ${ }^{26}$ Preselišvi se u travnju 1907. godine Horvat se uključio u društveni život Zagreba i počeo je predavati na donjogradskoj realnoj gimnaziji, trgovačkoj školi i nadbiskupskom liceju. Horvatova popularnost koju je stekao međimurskom povjesnicom i iskustvom u pisanju (poznavanju materije, izvorne građe i provođenju istraživanja), naveo je Juraj Kolarić [1998.], potaknuli su varaždinskog gradonačelnika Ljudevita Jurinca da mu se obrati za pisanje povjesnice grada Varaždina kojom bi se obilježio njegov sedamstoti jubilej. ${ }^{27}$ Horvat je na inicijativu koprivničkog gradonačelnika Jurja Vargovića, 24. rujna 1909. godine, prihvatio pisati povjesnicu podravskog grada, za što je dobio honorar od 2000 Kruna. Iako ga je priredio ranije, rukopis je tiskan 1943. godine. ${ }^{28}$ Kako bi mu omogućio istraživanja arhivske građe, navela je Kolar-Dimitrijević [1998.], ban Pavao Rauch »[...] dao je Horvatu jednogodišnji dopust, a onda se pobrinuo i za dozvolu za rad u Državnom arhivu u Beču - tamo je naišao na ar-

\footnotetext{
24 Mira KOLAR-DIMITRIJEVIĆ, »Život hrvatskog povjesničara i političara Rudolfa Horvata«, Dr. Rudolf Horvat - život i djelo, Koprivnica, 1998. (dalje: KOLAR-DIMITRIJEVIĆ, 1998a.), 8-21.

25 KOLARIĆ, 1998., 33.-34.

26 KOLAR-DIMITRIJEVIĆ, 1998a., 12.; Rudolf HORVAT, Povjest Medjumurja, Knjižara St. Kugli, Zagreb, 1907.

27 Ibidem, 33.

28 Usp. ERNEČIĆ, 1997., 9. i ERNEČIĆ, 1998., 85.
} 
hivsku građu o povijesti Varaždina i ostalih hrvatskih gradova, u čemu je Horvat i pionir i jedan od najplodnijih pisaca hrvatske povjesnice « ${ }^{29}$

Tijekom i između dvaju svjetskih ratova, Horvatova djelatnost povezanija je s njegovim političkim stajalištima i angažmanom. Godine 1915. osnovom prijave o njegovim političkim stavovima, bez saslušanja je imenovan »političkim sumnjivcem«. Kao običan vojnik je dodijeljen u pukovniju u mađarskom SzatmarMenetu, maltretiran od mađarskog vodstva obolio je na srcu, pa je boravio $u$ posadnoj bolnici u Košicama, da bi tek na intervenciju bečkog Ratnog ministarstva, vjerojatno uz pomoć Pavla Raucha, bio oslobođen 5. ožujka 1916. godine i vraćen na rad u zagrebački Zemaljski arhiv. ${ }^{30} \mathrm{U}$ varaždinskom je gradskom kazalištu 21. listopada 1918. godine, priredio predavanje Socijalne uredbe u starom Varaždinu. ${ }^{31}$ Odlukom Zemaljske vlade 1919. godine nepropisno je privremeno umirovljen. Za Hrvatsku republikansku stranku radio je sve do 1924. godine, kada je, istaknula je autorica, »[...] kritizirajući Radićev upis stranke u Seljačku internacionalu u Mosvki, kao i zbog namjere da stvori novu seljačku stranu, došlo do njegovog razlaza sa Stjepanom Radićem, te se sam povukao iz kandidature na izborima u veljači 1925., pri čemu je nastavio rad na kulturno-političkom radu vezanom za popularizaciju hrvatske povijesti [..] Horvat se u tom vremenu snažno veže kao član Hrvatskog sokola za organizaciju proslave 1000. godišnjice hrvatskog kraljevstva. [...] Horvat 12. srpnja 1925. govori u Varaždinu predvodeći i hrvatske Sokole «. ${ }^{32}$ Horvat je 1926. godine reaktiviran kao profesor povijesti na zagrebačkoj Drugoj velikoj gimnaziji, a nakon proglašenja oktroiranog ustava smanjio je svoje aktivnosti. Protivio se ukidanju srednjih škola u Hrvatskoj, odbijao je surađivati s režimskim organizacijama, pa je 1932. godine ponovno umirovljen. ${ }^{33} \mathrm{U}$ svezi s tim periodima života autorica je dodala: »Međutim mnogo radi na povijesti hrvatskih gradova i gotovo da nema niti jednog mjesta $u$ sjevernoj Hrvatskoj o kojem Horvat ne bi nešto napisao i on je isječke objavljivao vrlo vješto u pojedinim lokalnim novinama, kontinuirano ili s prekidima, ukoliko se pojavila opasnost zabrane. Mnogo od tog što je napisano nije izašlo u monografskom obliku, odnosno nisu objavljeni svi zamišljeni svesci «. ${ }^{34}$ Nakon proglašenja NDH, Horvat je reaktiviran kao profesor povijesti na zagrebačkoj Vojničkoj akademiji, saborskim zastupnikom je imenovan 1941., a početkom 1944. godine profesorom hrvatske povijesti na Filozofskom fakultetu u Zagrebu.

KOLAR-DIMITRIJEVIĆ, 1998a., 13.

$30 \quad$ Ibidem, 15.

31 s. a., »Pučka prosvjeta. Pučko predavanje u Varaždinu«, Volja naroda, 17. listopada 1918., br. 16, 4.

32 KOLAR-DIMITRIJEVIĆ, 1998a., 16. i 17.

33 »Horvat, Rudolf«, Hrvatski biografski leksikon, ur. Trpimir Macan, Zagreb, 2002., 657.

34 KOLAR-DIMITRIJEVIĆ, 1998a., 18. 
U svezi s tim periodom Horvatova života, Zvonimir Despot [1998.] je istaknuo da je Horvat nakon uspostave komunističkog režima bio optužen da je u djelima Hrvatska na mučilištu (1942.) i Ljetopis Hrvatske 1918.-1942. u zborniku Naša domovina veličao ustaštvo. Na prvom je suđenju oslobođen, ali na drugom suđenju 8. ožujka osuđen na »oduzimanje političkih i građanstvih prava kroz deset godina. Nakon osude izgubio je i mirovinu te je ubrzo, 25. svibnja 1947. u Zagrebu umro u potpunoj neimaštini i zaboravu «. ${ }^{35}$ Osuda mu je uz ime, zaključio je Dražen Ernečić [1997.], »vezala etiketu osuđenog povjesničara čija su djela nepodobna za objavu «. ${ }^{36}$ Povjesničari time tumače Horvatov izostanak $u$ hrvatskoj historiografiji do početka 1990-ih kada se revidira njegov doprinos historiografiji te se tiskaju pretisci njegovih knjiga i dotada neobjavljenih rukopisa.

\section{PROSLAVA 700-GODIŠNJICE GRADA VARAŽDINA (1909.)}

Ideja o proslavi sedamstotog jubileja otkad je grad Varaždin od kralja Andrije II. dobio povlastice slobodnog i kraljevskog grada (1209.) pojavila se već 1901. godine kad je »jedan prijatelj« u Varaždinskom viestniku gradskoj vlasti predložio da $\mathrm{u}$ idućih sedam godina, u gradski proračun, uvrštava iznos za pokriće troškova proslave i da koji trg ili ulicu prozove imenom kralja darovatelja. ${ }^{37}$ Odluku o ugovaranju pisanja povijesti grada Varaždina s Horvatom jednoglasno su na sjednici 26. travnja 1909. godine prihvatili članovi gradskog Političkog prosvjetnog odbora. Među njima je bio budući Veliki župan Varaždinske županije Stjepan pl. Belošević, prijašnji gradonačelnik Gustav Breitenfield, javni bilježnik Oskar pl. Kiš, trgovac Aleksandar Dočkal, veletrgovac i veleposjednik Stjepan Leitner, fizik Edo Spitzer i odvjetnik dr. Nikola Pečornik, Gradonačelnik je izvjestio da je određen širi odbor za proslavu jubileja i da se »u spomen te proslave napiše // obširna povijest grada Varaždina i da se taj posao povjeri poznatom povjestničaru kr: gimnazijalnom professoru Dr: Rudolfu Horvatu u Zagrebu. I Povodom tog zaključka obratio se je gradski načelnik na Dr: Rudolfa Horvata, koji se je pismom od 5/IV/09 izjavio pripravnim napisati izcrpivu povjest grada Varaždina, koja bi imala sastojati od 5 diela i to iz povjesti političke, // pravne, kulturne, gospodarske i socijalne. - Vrieme kada bi mogao dovršiti to obsežno djelo ne može unapred ustanoviti. Ustanovljenje honorara prepušta posve na volju sl. gr. zastupstva, primječuje da mu matica hrvatska plaća $80 \mathrm{Kr}$ po štampa-

\footnotetext{
35 Zvonimir DESPOT, »Politički put dr. Rudolfa Horvata«, Dr. Rudolf Horvat - život $i$ djelo, Koprivnica, 1998., 68.

36 ERNEČIĆ, 1997., 10.

37 s. a., »Sedamstogodišnjica grada Varaždina«, Varaždinski viestnik, 24. kolovoza 1901., br. 34, 2.
} 
nom arku od 16 stranica [...] «.38 Članovi odbora pismeno su se obratili Horvatu i odluku o povjesnici su donijeli nakon Horvatove potvrde početkom travnja. Zaključak tog odbora jednoglasno je usvojen 28. travnja na sjednici Poglavarstva grada Varaždina, ${ }^{39}$ ali u točki zapisnika ne navodi se predujam od 300 Kruna, koji se spominje u dosadašnjim istraživanjima. U kazalu općih spisa gradske vlasti za godinu 1909., stoji: Horvat Dr. Rudolf potpora 600K, Horvat Rudolf izvještaj o povijesti Varaždina. [...] Horvat Rudolf izvj. za zastav povijesti. ${ }^{40}$

Odluku gradskih vlasti novine Naše pravice i Hrvatske pravice objavile su ubrzo i u istovjetnom tekstu. ${ }^{41}$ Početkom svibnja pisac članka u Našim pravicama pitao se kako će frankovci najdostojnije proslaviti jubilej. ${ }^{42}$ U lipnju je u Hrvatskim pravicama pisac predložio da se u vrijeme proslave jubileja održi izložba, lokalna ili županijska. ${ }^{43}$ Ubrzo se, $u$ istim novinama upozorava gradsku vlast da se jubilej ne bi trebao prirediti »na vrat na nos«, te da se, ako se već zbog novčanih prilika ne može postaviti skupocjeni spomenik, neku ulicu ili trg, koji »ne odgovaraju ni hrvatskom obilježju, ni današnjem duhu vremena«, preimenuje imenom hrvatskog ili varaždinskog rodoljuba i velikana. ${ }^{44}$ Sredinom srpnja gradska vlast je odlučila proslavu spojiti s dolaskom biskupa u Varaždin u rujnu kako bi obavio vizitaciju i svetu potvrdu. ${ }^{45}$

Ustrojeni posebni odbor će tijekom proslave prirediti »skromnu izložbu starina«. Putem Naših pravica pozvalo se čitatelje da povelje i spise o gradu Varaždinu predaju na ruke prof. Juliju Jankoviću ili dr. Nikoli Pečorniku. ${ }^{46}$ U Našim pravicama nepotpisani pisac je donio pregršt podataka o povijesnim prilikama u Varaždinu od 1209. godine do početka XX. stoljeća osvrnuvši se i na suvremena zbivanja o gospodarstvu, trgovini, obrtu, siromaštvu i stanovništvu u gradu. ${ }^{47}$ Sažimajući ideje o proslavi, pitanjem »Pa što će dakle naš mili Varaždin?«, osvr-

38 DAVŽ), [0016] GPV - Varaždin (1850.-1918.), Opći ili »politički spisi« 1850.-1918., 6570/1909, točka 21.

39 DAVŽ, [0016] GPV - Varaždin (1850.-1918.), Zapisnici sjednica poglavarstva, zastupstva i pojedinih odbora 1852.-1918., Zapisnici za 1909. godinu, sjednica 28. travnja 1909., s. p.

40 DAVŽ, [0016] GPV - Varaždin (1850.-1918.), Kazala k urudžbenim zapisnicima »političkih spisa« 1851.-1918., 1909. godina, s. p.

41 s. a., »Povijest grada Varaždina.«, Naše pravice, 29. travnja 1909., br. 17, 4-5.; s. a., »Povijest grada Varaždina.«, Hrvatske pravice, 1. svibnja 1909., br. 18, 5-6.

42 s. a., »Gradsko kazalište«, Naše pravice, 6. svibnja 1909., br. 18, 5.

43 s. a., »Jubilej grada Varaždina i obrtništvo.«, Hrvatske pravice, 12. lipnja 1909., br. $24,3$.

44 s. a., »Valjan predlog u zgodno vrieme.«, Hrvatske pravice, 19. lipnja 1909., br. 25, 2.

45 s. a., »Iz skupštine gradskog zastupstva.«, Hrvatske pravice, 17. srpnja 1909., br. 29, 3.; s. a., »Proslava 700-godišnjice grada Varaždina.«, Naše pravice, 22. srpnja 1909., br. 29, 3.

46 s. a., "K proslavi sedamsto-godišnjice grada Varaždina.«, Naše pravice, 29. srpnja 1909., br. $30,5$.

47 s. a., »K sedamstogodišnjici grada Varaždina I.«, Naše pravice, 29. srpnja 1909., br. 30, 3-4. 
nuo se i na buduću povjesnicu. Pitao se hoće li biti popularno ili znanstveno djelo s povijesnim prilozima te je obrazložio da ne može biti »gotova, ako je ozbiljno zamišljena, prije - tri godine [...] «, da bi R. Horvat trebao dati »što jasniju kulturnu sliku našega grada: život gradjanski, život cehova itd. Oni mali ljudi, nas zanimaju više od veliko županskih instalacija«. Osim mišljenja da su pripreme zavite »koprenom neizvjesnoti i tajnosti«, smatrao je da spajanje proslave sa svetom potvrdom, » tog naša pamet 'ne dohita' «. ${ }^{48} »$ To je prava mizerija, znak varaždinske dekadence«, čita se u Našim pravicama koje su predložile gradskoj vlasti da, ako se ne želi »obrukati«, proslavu odgodi za dvije-tri godine, jer tako »misle svi razboritiji ljudi u našem gradu $« .{ }^{49}$ Mjesec dana prije proslave u Hrvatskim pravicama se čita: »Pripreme su dakle dosta rano započele, ali su i isto tako rano 'zaspale'. Glavna točka proslave, historija grada Varaždina je jedva započeta. Prije godinu dana ovo djelo ne može biti dovršeno«, pa se predložila odgoda kako bi se prištedjela blamaža. ${ }^{50}$ Početkom rujna Naše pravice tiskaju da im je drago što se s njima slažu »prijatelji« iz Hrvatskih pravica, koji predlažu odgodu na 1911. ili 1912. godinu, te da dotada uplatama u proračun "sabere fond za proslavu «. ${ }^{51}$ Sredinom rujna čita se o odogodi. ${ }^{52}$

Skromnu proslavu 14. studenog 1909. godine obilježila su varaždinska društva. Hrvatske pravice držale su da je jedinu »uspješnu « priredilo Katoličko djetićko društvo: zabavi su uz gradsku glazbu pridružili i predavanje Horvata o »zanimljivim« zgodama iz povijesti grada, koje su građani u kazališnoj restauraciji pratili »s najvećom pomnjom i zanimanjem [...] Zanosnim srcem, domoljubnim oduševljenjem, s najvećom sigurnosti povjesnog znanja crtao je govornik sve važne povijesne događaje grada Varaždina od najstarijega doba pa sve do ilirskog pokreta, koji je i u Varaždinu našao umne pobornike «. ${ }^{53} \mathrm{Na}$ dan grada Varaždina, u župnoj crkvi sv. Nikole, nakon abacijalne mise, tijekom propovijedi su crkvi predane dvije viseće svjetiljke za svetohranište. ${ }^{54}$ Sredinom prosinca Naše pravi-

\footnotetext{
48 s. a., »K sedamstogodišnjici grada Varaždina. II.«, Naše pravice, 5. kolovoza 1909., br. 31, 3-4.

49 s. a., »Gajeva stogodišnjica i Varaždin.«, Naše pravice, 19. kolovoza 1909., br. 33, 5.

50 s. a., »Sedamstogodisnjica grada Varaždina. «, Hrvatske pravice, 28. kolovoza 1909., br. 35, 5.

51 s. a., »Sedamsto - godišnjica grada Varaždina.", Naše pravice, 2. rujna 1909., br. 35, 6.

52 s. a., »Proslava 700-godišnjice grada Varaždina odgodjena.«, Naše pravice, 9. rujna 1909., br. 36, 5.; s. a., »Odgodjena proslava 700-godišnjice.«, Hrvatske pravice, 18. rujna 1909., br. 38, 5.

53 s. a., »Proslava 700-godišnjice grada Varaždina.«, Hrvatske pravice, 27. studenog 1909., br. 48, 5.; s. a., »Katoličko djetićko društvo u Varaždinu «, Hrvatske pravice, 13. studenog 1909., br. 46, 7.; s. a., »Društvena zabava katoličkog djetićkog društva«, Naše pravice, 18. studenog 1909., br. 46, 3-4.

54 s. a., »Proslava 700-godisnjice Varaždina u župnoj crkvi sv. Nikole«, Hrvatske pravice, 4. prosinca 1909., br. 49, 7.; s. a., »* Proslava 700 godisnjice u crkvi sv. Nikole«, Hrvatske pravice, 11. prosinca 1909., br. 50, 4 .
} 
ce kritizirale su izostali doprinos gradske vlasti toj skromnoj proslavi. ${ }^{55}$ Spram prethodnih »promislioca«, mišljenje o ugovorenoj povjesnici izrazio je Pukler $\mathrm{u}$ Hrvatskim pravicama u ožujku 1910. godine. Uspoređujući povjesnicu Požega Julija Kempfa (1910.) koju je Požežanin pisao dvanaest godina, Pukler je smatrao da bi se $u$ pisanju povjesnice trebala ispuniti tri uvjeta: povjeriti stvar stručnjaku, dati mu vremena kako bi »savladao« postojeći objavljeni i arhivski materijal i dati mu sredstva. Imajući na umu da je Horvat u Varaždinu »proboravio« više godina, Pukler se pitao: »Hoće li ta povijest biti povijest lih grada Varaždina, hoće li biti svestrana i opširna, da li ilustrovana, nije nam točno poznato. Svakako neka bude što uspješnija, neka bude snabdjevena svim uvjetima dotjerane i kritičke povijesti. [...] Radje počekati, nego da to bude djelo površno, radje sada žrtvovati i materijalne potpore, nego da se kasnije kajemo ${ }^{56}$ Proslave su se nastavile sljedeće godine: 15. lipnja je I. varaždinski dobrovoljni djevojački pjevački i tamburaški zbor u Varaždinu prvim javnim nastupom priredio koncert $\mathrm{u}$ kazalištu. ${ }^{57}$

\section{POTVRDA HORVATOVIH ARHIVSKIH ISTRAŽIVANJA}

Uz istraživanja u arhivima u Beču, Budimpešti i Grazu, novinski članci i sačuvana arhivska građa, ponajviše iz Hrvatskog državnog arhiva, potvrđuju da je Horvat od 1909. godine nadalje vršio istraživanja o povijesti grada Varaždina i u tadašnjem Kraljevskom zemaljskom arhivu u Zagrebu i u Varaždinu. Temeljem istraživanja Horvat je već srpnju 1910. godine u Hrvatskim pravicama u članku Povijest grada Varaždina objavio svoje zaključke o postojanju Varaždina u srednjovjekovno doba s osvrtom na 1209. godinu. Isti članak će Horvat šest godina poslije objaviti u novinama Hrvatsko pravo. ${ }^{58}$ Zaključkom sjednice Poglavarstva grada Varaždina 27. lipnja 1910. godine odobrena mu je molba da mu gradska vlast u Kraljevski zemaljski arhiv u Zagrebu »odašalje njeke stare gradske spise i protokole na njegovu uporabu kod sastavka poviesti, a ujedno, da mu se na izplatu doznači svota od $300 \mathrm{Kr}$. u ime imanog troška za putovanje u Beč i Gradac, gdje je studirao arhive i izvrstan materijal za poviest grada Varaždina sabrao«. ${ }^{59}$ Prema Hrvatskim pravicama, Horvatu je rad u Beču omogućen dozvolom zajedničkog

55 s. a., »700 godišnjica slobodnog i kr. grada Varaždina.«, Naše pravice, 16. prosinca 1909., br. 50, 3.

56 PUKLER, »Kakova da bude povijest Varaždina?«, Hrvatske pravice, 12. ožujka 1910., br. 11, 2.

57 s. a., »I. varaždinski dobrovoljni djevojački pjevački i tamburaški sbor u Varaždinu.«, Naše pravice, 2. lipnja 1910., br. 23, 5.

58 [Rudolf HORVAT], »Postanak grada Varaždina«, Hrvatske pravice, 9. srpnja 1910., br. 28, 1-2.; Hrvatsko pravo, 23. rujna 1916., br. 39, 2-3.

59 s. a., "Sa naše gradske vijećnice.«, Naše pravice, 1. rujna 1910., br. 36, 4. 
ministarstva financija. ${ }^{60} \mathrm{U}$ kolovozu te godine, Naše pravice su izvijestile da će Horvat doći u Varaždin kako bi istraživao arhive za pisanje povjesnice. ${ }^{61}$

Osim osobnim uvidom pri dolasku u Varaždin, Horvat je arhivsku građu iz varaždinskog arhiva istraživao u prostorijama Kraljevskog zemaljskog arhiva. Urudžbene knjige zagrebačkog arhiva zabilježile su dopise kojim je zagrebački arhiv za povjesničara molio posudbu građe iz Varaždina, ali i molbe kojima je varaždinska gradska vlast od zagrebačkog tražila njezin povrat. Dopisi su nastajali od 1910. do kraja 1920-ih godina. Poglavarstvo grada Varaždina je prije 10. listopada 1910. godine Horvatu poslalo izvorne zapisnike političkih (1703.-1754.) i sudskih sjednica (1703.-1753.) gradskog zastupstva. ${ }^{62}$ Dva dana poslije Horvatu je odobrena molba da ga se, uz smanjenje nastavnih sati na zagrebačkoj gimnaziji (šest tjedno), dodijeli na rad u zagrebački arhiv. ${ }^{63}$ U Horvatovo ime, arhiv je dopisom 25. studenog 1910. godine »uljudno « molio gradsku vlast u Varaždinu da im pošalje dodatne zapisnike, političke (1592.-1602.) i sjedničke (1587. nadalje). ${ }^{64}$ Oni i zahtjev za slanjem potvrde primitka poslani su mu 5. prosinca, ${ }^{65}$ što je zagrebački arhiv ubrzo i potvrdio. ${ }^{66}$

Horvat građu istražuje i nakon 1912. godine, kada se smatralo da je dovršio glavninu rukopisa, što potvrđuju daljnji dopisi. Poglavarstvo grada Varaždina dopisom je 25. svibnja 1916. godine zagrebački arhiv podsjetilo da na raspolaganju već pet i pol godina ima zapisnike političkih (1592.-1602.) i sudskih sjednica (1587. nadalje), kako je držalo da ih ne koristi, molilo ih je na povratak jer ih vlast »vrlo nužno potrebuje«. Nakon ove »požurnice«, Poglavarstvo je molbom 10. siječnja 1917. godine »podrugi« put od zagrebačkog arhiva tražilo povrat tih zapisnika, inače će biti »prisiljeno potražiti intervenciju više oblasti«. U dopisu dan poslije, 11. siječnja Poglavarstvo je od zagrebačkog arhiva tražilo povrat posuđenih političkih (1703.-1754.) i sudskih zapisnika (1703.-1735.) jer Rudolf Hor-

60 s. a., "Važni dokumenti za gradju povijesti podravskih gradova.«, Hrvatske pravice, god. IV, br. 33, 13. kolovoza 1910., 5.

61 s. a., »Važni dokumenti za gradju poviesti podravskih gradova.«, Naše pravice, 18. kolovoza 1910., br. 34, 5 .

62 HR-HDA-511. Hrvatski državni arhiv (dalje: HDA), Urudžbene knjige, zapis za spis 171/1910, 10. listopada 1910.

63 HR-HDA-511. HDA, Spisi 1791-1945, Dopis Kraljevskom hrvatsko-slavonsko-dalmatinskom zemaljskom arhivu u Zagrebu (dalje: KZA) 12. listopada 1910.

64 HR-HDA-511. HDA, Spisi 1791-1945, Dopis Poglavarstva grada Varaždina (dalje: PGV) KZA-u 25. studenog 1910.

65 HR-HDA-511. HDA, Spisi 1791-1945, Dopis PGV-a KZA-u 5. prosinca 1910.

66 HR-HDA-511. HDA, Urudžbene knjige, zapis za spis 213/1910.: »213., 16./XII., R.a., potvrđuje poglavarstvu grada Varaždina primitak gornjih spisa na uredov. porabu, na br. 212«. 
vat »do danas te povjesti napisao nije «. ${ }^{67} \mathrm{U}$ urudžbenoj knjizi zagrebačkog arhiva, uz zabilješku ovih molbi kojima se »urgira« povratak građe, stoji unos da su 20. siječnja vraćeni prvi posuđeni zapisnici (politički 1703.-1753., sudski 1703.-1735.), no i oni drugi (politički 1592.-1602. i sudski 1587. nadalje) « ${ }^{68}$ Međutim, Poglavarstvo je 3. veljače 1917. godine obavijestilo zagrebački arhiv da, iako su vraćeni drugi zapisnici, oni prvi i nisu, pa »umoljava se sve te spise čim prije amo vratiti [...] jer ih gradsko poglavarstvo silno treba«. Arhiv je molbu »udovoljio« 14 . veljače 1917. godine. ${ }^{69}$ Ova peripetija oko povrata posuđene građe možda je utjecala na stav varaždinske vlasti da molbe idućih tražitelja ne odobri. ${ }^{70}$

Poglavarstvo grada Varaždina molbe za povrat građe šalje i tijekom 1920-ih godina. Misleći kako politički (1703.-1754.) i sudski zapisnici (1703.-1735.) nisu vraćeni, poslalo je dopis 23. srpnja 1923. godine za povrat građe ili da »saopći možebitne zaprijeke «. ${ }^{71}$ Zagrebački arhiv je dopisom 3. kolovoza 1923. godine izvijestio Gradsko poglavarstvo Varaždin da je traženu građu vratio u dva navrata početkom 1917. godine te »ustanovio« da ne posjeduje spise »koji ne bi bili već vraćeni «. ${ }^{72}$ Izgleda da ipak nije vraćena sva građa, jer je Kraljevski državni arhiv 30. rujna 1926. godine vratio »protokol varaždinskog mesarskog ceha, koji je bio na porabi dr. Rudolfu Horvatu, ${ }^{73}$ potvrda o primitku mu je vraćena 7. listopada. ${ }^{74}$ Zagrebački arhiv je dopisom 15. siječnja 1927. godine obavijestio varaždinsku gradsku vlast da su u tzv. »odijelenju 'Extronea' pronašli i poslali mu sudski zapisnik XV. stoljeća iz varaždinskog arhiva. Iako nisu znali kako je »došao k nji-

67 HR-HDA-511. HDA, Spisi 1791-1945, Dopis PGV-a KZA-u 25. svibnja 1916., 10. siječnja i 11. siječnja 1917.

68 HR-HDA-511. HDA, Urudžbene knjige, zapis za spis 18/1917.: »18., 20./I., R.A., vraća gradskom poglavarstvu u Varaždinu protokole od g. 1588, 1592-1602, 1703-1735 i 1703-1754, Na brojeve 16. i 17.«. Spis nedostaje.

69 HR-HDA-511. HDA, Spisi 1791-1945. Molba PGV-a KZA-u 3. veljače 1917. Usp. HR-HDA-511. HDA, Urudžbene knjige, zapis za spis 28/1917.: »[...] Udovoljuje se odmah. Riješeno pod brojem 30.«i usp. zapis za spis 30/1917.: »30., 14./II., R. A., dostavlja gradskom poglavarstvu u Varaždinu gradske protokole 18. vijeka., Na broj 28.« Spis nedostaje.

70 Odbili su molbe tadašnjega tajnika Zemaljskog arhiva Emilija Laszowskog od 18. kolovoza 1917. i 7. siječnja 1918. godine, a dopisom 31. siječnja 1918. godine savjetovali su mu neka nabavi prijepis građe ili neka dođe u Varaždin osobno je proučiti. HR-HDA-511. HDA, Spisi 1791-1945, Dopis KZA PGV-u 18. kolovoza 1917. / Dopis KZA PGV-u 7. siječnja 1918. / Dopis PGV-a KZA-u 31. siječnja 1918.

71 HR-HDA-511. HDA, Spisi 1791-1945, Dopis PGV-a Kraljevskom državnom arhivu u Zagrebu (dalje: KDA) 23. lipnja 1923.

72 HR-HDA-511. HDA, Spisi 1791-1945, Dopis KDA Gradskom poglavarstvu u Varaždinu (dalje: GPV) 3. kolovoza 1923.

73 DAVŽ, [0649] GPV - Varaždin (1918.-1941.), Opći spisi 1918.-1940., 8515/1926. Usp. HR-HDA-511. HDA, Spisi 1791-1945, Dopis KDA Zagrebu GPV-u 30. rujna 1926.

74 HR-HDA-511. HDA, Spisi 1791-1945, Dopis GPV-a KDA-u 7. listopada 1926. 
ma«, mislili su da je »možda zaostao« iza Horvata. ${ }^{75}$ Dva dana poslije gradska vlast sa zahvalnošću je potvrdila primitak građe. ${ }^{76}$ Pregled urudžbenih knjiga do 1941. godine pokazuje da se uz Horvatovo ime ne navodi sudbeni zapisnik iz XV. stoljeća. Je li moguće da ga je koristio netko drugi? Na temelju silnih dopisa između ovih institucija nije moguće posve točno ustvrditi točan prikaz posudbe i povrata arhivske građe, ustvrditi tko je bio u pravu ili u krivu: je li Horvat vratio svu građu ili nije. Izgleda da je Horvat tu građu vjerojatno proučavao, i nakon 1912. godine.

\section{RUKOPIS SE IŠČEKUJE VEĆ ČETVRT STOLJEĆA}

Sudeći prema novinama i arhivskoj građi, Horvat je krajem Prvog svjetskog rata i tijekom 1920-ih dolazio u Varaždin održati prikladna predavanja o povijesti ovog grada. Na poziv Hrvatskog akademskog ferijalnog kluba »Tomislav« 21. listopada 1918. godine održao je u zgradi gradskog kazališta predavanje Socijalne uredbe u starom Varaždinu. ${ }^{77}$ Na poziv Hrvatskog Sokola, 16. ožujka 1924. godine u "gradskoj gombaoni " govorio je o Tridesetogodišnjici smrti hrvatskog bana Tom Bakač-Erdödyja. ${ }^{78} \mathrm{U}$ godini kada se obilježavalo tisućljeće postojanja hrvatske države Horvat je 11. srpnja predavao o hrvatskoj povijesti i tisućljetnom narodnom životu. ${ }^{79}$ U Osobnom fondu Rudolfa Horvata u Hrvatskom državnom arhivu čuvaju se povjesničarove bilješke o njegovim predavanjima: na par papirića Horvat je olovkom ispisao predavanja s podacima o datumu, naručitelju, mjestu održavanja i temi. Na jednom je papiru počeo: »Javno sam govorio na trgovima 1925. [...] 12. srpnja u Varaždinu [...]«, pa je dodao » Predavao sam g. 1924. / 8. lipnja [...] u Varaždinu Hrv. Sokol o 300god. Tom Erdeda «, ${ }^{80}$ pri čemu se primjećuje da je zabilježio drugačiji datum.

75 DAVŽ, [0649] GPV - Varaždin (1918.-1941.), Opći spisi 1918.-1940., 585/1927. Usp. HR-HDA-511. HDA, Spisi 1791-1945. Dopis KDA GPV-u 15. siječnja 1927.; Prema informaciji mr. sc. Ladislavu Dobrici, višem arhivistu HDA, fond Extronea, ne postoji.

76 HR-HDA-511. HDA, Spisi 1791-1945, Dopis GPV-a KDA-u 17. siječnja 1927.

77 s. a., "Pučka prosvjeta. Pučko predavanje u Varaždinu«, Volja naroda, 17. listopada 1918., br. 16, 4.; s. a., »Dojam dogadjanja u Varaždinu. Manifestacije u kazalištu«, Volja naroda, bez br., 22. listopada 1918., 2.

78 s. a., »Interesantno predavanje o Tomi Bakač-Erdödy-u«, Hrvatsko jedinstvo, 8. ožujka 1924., br. 4, 3..; s. a., »Interesantno predavanje«, Hrvatsko jedinstvo, 15. ožujka 1924., br. 5, 2.

79 s. a., »Raspored proslave 1000-godišnjice u Varaždinu dne 11. i 12. srpnja 1925.«, Narodno jedinstvo, 9. srpnja 1925., br. 8, 2., s. a., »Proslava 1000-godišnjice hrvatske državnosti.«, Narodno jedinstvo, 23. srpnja 1925., br. 10, 2.

80 HR-HDA-799. Horvat Rudolf. 1.1. Bilješke R. Horvata o vlastitim predavanjima, Javno sam govorio na trgovima 1925. 
U studenom 1919. godine varaždinske novine Slobodni gradjanin objavljuje dva članka Što je sa poviješću grada Varaždina? Prvim se člankom podsjetilo Poglavarstvo grada Varaždina na naručenu povjesnicu i "predujam « koji je dodijelio piscu. Nastavile su, iako se u raznim publikacijama čitalo o crticama iz povijesti grada, »prošle su godine«, a povjesnice »nema, pa nema « ${ }^{81}$ Krajem mjeseca Horvat je putem novina odgovorio da na povjesnici treba raditi »barem desetak godina zbog temeljitog proučavanja izvora o varaždinskoj povijesti u arhivima u Beču, Budimpešti, Grazu i Zagrebu, što je, uz nedovoljnu novčanu potporu 300 Kruna, činio tijekom svog slobodnog vremena i školskih praznika. Nastavio je da je crtice o varaždinskoj povijesti objavljivao u časopisima, novinama, zasebnoj studiji (1912.) za što je dobio 300 Kruna, da je velik dio proučene građe obradio za tisak, ali povjesnicu nije objavio zbog ratnih prilika. ${ }^{82}$ Njegove riječi o u dva navrata isplaćenom iznosu od 300 Kruna potvrđuju zabilješke iz kazala općih spisa, da je Horvatu isplaćeno 600 Kruna. Deset godina poslije, Narodno jedinstvo Horvatovu crticu O milosrđu građana u godini 1601., započele su mišlju da Horvat na povjesnici radi »već preko 20 godina . $^{83}$

Potaknut jubilarnom 725. godinom grada Varaždina i 300. godinom postojanja varaždinske gimnazije, rođeni Varaždinac i umirovljeni staropazinski župnik Stjepan Kropek je 14. travnja 1933. godine člankom Kada ćemo dobiti povijest grada Varaždina? podsjetio Gradsko poglavarstvo Varaždin da je od ugovaranja povjesnice prošlo četvrt stoljeća. Obrazložio je da prije više od pola stoljeća, prema riječima tada pokojnog gimnazijskog profesora Julija Jankovića, niti jedan zagrebački priznati historik nije prihvatio pisanja povjesnice grada Varaždina zbog opsežnosti arhivskog materijala i nepostojanja sekundarnih izvora. Kropek se osvrnuo na historiografska djela o Varaždinu, iz pera L. Ebnera, I. KukuljevićaSakcinskoga, J. Jankovića, na njemačkom jeziku tiskan rad nepoznatog autora, S. Valdeca, S. Beloševića i K. Filića. Smatrao je da bi Horvatovo djelo trebalo biti nalik njegovoj studiji Varaždin koncem 16. vijeka. Dodao je da »čeka u rukopisu, da bude izdano«, da »predviđa nekih 25-30 štampanih araka, a biće ukrašeno mnogim slikama. Mimograd spominjem, da isti uvaženi pisac ima gotovu u rukopisu i opširnu Povijest župne crkve sv. Nikole u Varaždinu s mnogim interesantnim podacima ${ }^{84}$ Čini se da je župnik imao prilike osobno vidjeti rukopis. Napo-

81 s. a., „Što je sa poviješću grada Varaždina?«, Slobodni gradjanin, 1. studenog 1919., br. 32, 4.

82 Rudolf HORVAT, »Što je s povješću grada Varaždina?«, Slobodni gradjanin, 29. studenog 1919., br. 36,4 .

83 Rudolf HORVAT, »O milosrdju varaždinskih gradjana u godini 1601.«, Narodno jedinstvo, 7. veljače 1929., br. 6, 3 .

84 Stjepan KROPEK, »Kad ćemo dobiti povijest grada Varaždina?«, Varaždinske novosti, 14. travnja 1933., br. 175, 9. 
sljetku, predložio je da se tiska 1934. godine, povodom obilježavanja spomenutih obljetnica.

\section{IZ KORESPONDENCIJE IZMEĐU HORVATA I GRADA VARAŽDINA}

Posljednja kritika je očito potaknula Poglavarstvo grada Varaždina da priču o sastavu povjesnice privede njezinom kraju, o čemu svjedoče sačuvana korespondencija između Horvata i gradske vlasti, te zapisnici skupštinskih sjednica gradske vlasti - koji pak obiluju novim saznanjima o rukopisu. Strojopisnim »Referatom « u ljeto 1933. godine izvješćuje se o rukopisu, a u nastavku podsjetnika tipkanog 16. kolovoza, dan poslije, gradonačelnik bilježi predložak pisma povjesničaru i uputu računovodstvu da provjeri predujam koji je povjesničar dobio za pisanje povjesnice:

Referat.

G. Dr. R u d olf H o r v a t profesor u Zagrebu imade dogotovljenu povjest grada Varaždina, koja obasiže preko 30 štampanih tabaka, a koju povjest je još 1903. g. poručilo gradsko zastupstvo.

Obzirom da 1934. godine slavi realna gimnazija 300 godišnjicu opstanka, domaće vatrogasno društvo opet 70 godišnjicu, to bi se gornje proslave održale na godinu zajedno sa 725 godišnjicom opstanka grada Varaždina, pa bi se imala povesti akcija za otkup gornjem djela, da grad jednom dodje do svoje povijesti.

Varaždin, dne 16. VIII. 1933.

$<$ Na načelničkom listu >

Pred: Grad Varaždin povijest grada.

Vždin ${ }^{17} /$ VIII 933

Gosp. Dr. Horvat Rudolfu profesoru Zagreb.

Prema svojedobnom sporazumu iz godine 1903. primili ste se posla oko sastava historije grada Varaždina, i u tu svrhu podigli predujam. // kako je već proteklo 30 godina od tog vremena - umoljavate se da obavijestite ovo načelstvo da li ste to djelo i kom opsegu te u kojim smjernicama obradili i uz koje uslove biste voljni da ga predate ovom načelstvu.

Ujedno Vas molim, da još pridržane podatke iz ovogradske arhive izvolite ovogradskom načelništvu dostaviti.

Izvolite Gospodine profesore primiti uverenje mog poštovanja. [potpis] 
II

Gradskom računovodstvu Vždin

Godine 1903. sklopljen je ugovor između gradske općine i profesora Dra Rudolfa Horvat iz Zgba za sastav povjesnice grada // Varaždina. Poziva se naslov, da izvidi koliki je predujam isplaćen Dru Horvatu u svrhu.

[potpis]

III. p? ${ }^{15} /$ IX $933 .{ }^{85}$

Pisac »Referata« donosi netočnu godinu ugovaranja povjesnice (1903). Na poleđini strojem prepisanog upita gradskom računovodstvu, ni tjedan dana poslije računovodstvo rukom odgovara da povjesničarev predujam »ne pridolazi iz očevidnosti ovouredskih knjiga «. ${ }^{86} \mathrm{~S}$ obzirom na tu obavijest koja je stigla početkom rujna, gradonačelnik je taj odgovor skupa s pristiglim Horvatovim pismom, proslijedio Prosvjetnom odboru.

Osim što je najznačajniji spis u predmetu, to pristiglo pismo je ujedno i najvažnije od tri sačuvana Horvatova pisma upućena Gradskom poglavarstvu Varaždin. Gusto ispisavši četiri stranice arka papira 24. kolovoza 1933. godine, Horvat je iznio mišljenje o dogovoru pisanja povjesnice i rukopisu. Nakon dva dana, na posljednjoj strani pisma ispod Horvatovih riječi, gradonačelnik Stjepan Novaković je zabilježio preporuku Prosvjetnom odboru da prihvati traženi honorar:

Slavnom gradskom načelstvu / u / Varaždinu.

Jučer sam primio cijenjeno pismo g. Novakovića, vršioca dužnosti gradonačelnika. Pismo nosi službeni broj 13.097 i datum 17. augusta, ali je odaslano tek 22. kolovoza, kako se vidi iz poštanskog žiga. Na to pismo čast mi je odmah odgovoriti, i to u 2 smjera. Najprije moram od sebe odbiti neke netočnosti, koje sigurno počivaju na krivim informacijama, što ih je dobio g. senator Novaković od izvjesne - meni nesklone - ličnosti. Zato želim prikazati cijelu osnovu moje »Povijesti slob. i kr. grada Varaždina«.

\section{Ad. I.)}

Gospodin Novaković piše doslovce ovako: »Prema svojedobnom sporazumu iz godine 1903. primili ste se posla oko sastava historije grada Varaždinu i u tu svrhu podigli predujam. Kako je već proteklo 30 godina od tog vremena, umoljavate se, da obavijestite ovo načelstvo, da li ste to djelo i u kom opsegu te u kojim

85 DAVŽ, [0649] GPV, Korespondencija GPV i RH, 13097/1933.

86 DAVŽ, [0649] GPV, Korespondencija GPV i RH, 14508-1933. Usp. »Izvj[eštaj]. o predujmu za zastav povijesti. 14.508«. DAVŽ, [0649] GPV - Varaždin (1918.-1941.), Kazala općih spisa 1918.1941., Kazalo za 1933. godinu, s. p. 
smjernicama obradili i uz koje uslove ste voljni da ga predate ovom načelstvu«. Na taj dio pisma odgovaram:

1.) Krivo je označena godina 1903. jer je zastupstvo grada Varaždina od mene naručilo povijest Varaždina godine 1909, kada se slavila 700 godišnjica grada. O tom se svatko može uvjeriti, ako pogleda zapisnike sjednica gradskog zastupstva godine 1909.

2.) Prema tom ne slijede, da je »već proteklo 30 godina«, otkako preuzeh zadaću, da pišem povijest Varaždina. Faktično su protekle 24 godine, a da sam pokojnim gradonačelnicima dru. Jurincu i dru. Magdiću odmah rekao, da ću za obradbu povijesti grada Varaždina trebati 25 godina. To je potvrdio i (sa mnom uvijek prisutni) profesor Julije Janković, koji je otvoreno izjavio, da se tog posla nije primio samo zato, što se uslijed svoje poodmakle dobi ne nada, da bi mogao poživjeti tako dugo, koliko je potrebno za sastav povijesti grada Varaždina. U ostalom svaki pravi stručnjak lako će razumjeti, da se takvo djelo ne može // pisati onako brzo, kako se pišu romani i novele. Historičar mora najprije proučiti sve izvore za povijest grada Varaždina, a ti se ne nalaze samo u Varaždinu, već također u 6 zagrebačkih arkiva, te u stranima arkivima (u Beču, Gracu i u Budimpešti). Ja sam iz svih arkiva za povijest Varaždina povadio preko 12.000 raznih bilježaka, koje mi tek pružaju mogućnost, da zaista napišem sustavnu povijest tog starog grada. Kada će čitatelji čitati moju knjigu, ne će ni slutiti, koliko me je muke i ustrajnosti stajalo prikupljanje materijala za sastavljanje povijesti Varaždina. Iz malih i na oko neznatnih bilježaka, do kojih se teško došlo, mora se sastaviti djelo, koje će svatko moći lako čitati, kao da je pripovijest.

3.) Nikada nijesam tražio nikakav predujam od grada Varaždina za pisanje povijesti. Ja sam jedino pričao gradonačelniku, kako bi trebalo proučiti spise »ratnog vijeća « koje je upravljalo varaždinskom krajinom, ali da se spisi tog vijeća nalaze u Gracu i u Beču, gdje je proučavanje spojeno sa znatnim troškom. Nato mi je gradsko zastupstvo doznačilo 200 (dvije stotine) kruna kao potporu za proučavanje tih spisa. Čudim se, što je izvjesna - meni nesklona - ličnost mogla iz ove neznatne potpore iskonstruirati nekakav predujam, koji niti sam tražio niti dobio. Bilo bi dobro, da se slavno gradsko načelstvo izvoli propitati, koliko su potpore za proučavanje arhivalija dobili pisci povijesti drugih gradova kod nas i u susjednim državama. Tada bi se jasno vidjelo da ja nijesam pazario s imovinom grada Varaždina, koji grad iskreno volim, jer sam u njem stekao kao gimnazijalac prvu kulturu.

4.) Pod konac svog pisma kažete:

»Ujedno Vas molim, da još pridržane podatke iz ovogradske arhive izvolite ovogradskom načelstvu dostaviti«. Ovaj me je zahtjev neugodno iznenadio. Ta ja osobno nijesam nikada baš nijedan spis iz gradskog arhiva u Varaždinu uzeo ili 
pozajmio! Listine su u prisutnosti prof. Julija Jankovića proučavao u gradskoj vijećnici. Zapisnike (protokole) gradskih sudova posudio je za mene kr. Zemaljski arhiv u Zagrebu, gdje sam ih proučavao, jer je za taj posao trebalo više godina. Čim sam koji protokol proučio i podatke zabilježio, vratio ga je arhivar dr. Ivan Bojničić službenim putem poglavarstvu grada Varaždina. Da se o tom osvjedočite, izvolite odrediti, da pouzdanik gradskog načelstva dođe u bivši »zemaljski«, a sada »državni« arhiv u Zagrebu, pa da pretraži uručbene zapisnike i poštovne knjige, gdje će se vidjeti kada je koji protokol u Zagreb došao i kada je vraćen u Varaždin. Mnogo mi je stalo do toga, da izvolite prihvatiti ovaj moj prijedlog, pa da se tako ušutka i ona izvjesna - meni nesklona - ličnost, koja je vjerojatno na mene bacila sumnju, da kod sebe još držim neke spise iz arhiva grada Varaždina. //

\section{Ad II.)}

Kada se latih prikupljanja izvora za povijest grada Varaždina, bilo mi je 36 godina. Sada sam starac od 60 godina. Razumjet ćete dakle moju vruću želju, da povijest grada Varaždina bude štampana godine 1934. S moje strane ne će tom biti nikakove zapreke, ako mi dragi Bog podijeli život i zdravlje. Ja sam naime glavni posao već dovršio, te sada pišem djelo na čisto, da bude sposobno za štampu. Velik je dio već i prepisan za štampu. To su kod mene vidjeli mnogi naši ljudi, medju ostalim i prof. Kropek, koji se kao rodjeni Varaždinac zanima za povijest Varaždina.

Obrađujući povijest Varaždina, podijelio sam ju u 2 dijela. Prvi dio čini opća (politička) povijest grada Varaždina. To je za pravo kronika ili slijedored dogadjaja u životu Varaždina. Drugi dio čini posebnu povijest, koja obradjuje ove teme:

1. Crkva u Varaždinu. Tu prikazujem povijest župne crkve sv. Nikole i povijest svih područnih kapela (prošlih i sadašnjih); zatim povijest varaždinskih samostana (franjevačkog, kapucinskog, uršulinskoga, isusovačkog i pavlinskoga); onda povijest samostanskih crkava, čazmanskog kaptola i rimokatoličkog svećenstva, napokon povijest invjeraca (protestanata, židova i pravoslavnih), te povijest židovske sinagoge i pravoslavne crkvice.

2. Š́kolstvo u Varaždinu. Tu iznosim povijest pučkih škola, djevojačke više škole, gimnazije, nekadašnje male realke, te šegrtske škole i nekadašnje trgovačke škole. Napose govorim o nekadašnjim učiteljima i profesorima, o životu đaka i o Zakmardijevom sjemeništu.

3. Gradsko poglavarstvo. Tu prikazujem nekadašnju upravu grada Varaždina. Poimenice iznosim vlast pojedinih organa (n. pr. gradskog suca ili načelnika, gradskog kapetana itd.) Tumačim, kako je tko mogao postati gradjaninom i kako se gubilo gradjanstvo. Mjesto sadašnjih gradskih zastupnika vodila su upravu grada t. zv. prisežnici, izmedju kojih su se birali senatori. 
4. Sudstvo u Varaždinu. Primjerima prikazujem postupak kod nekadašnjih sudova, koji bijahu djelomice javna bilježništva, jer se tu iznašahu oporuke, kupoprodajni ugovori i razni prosvjedi. Gradski je sud izricao osude u gradjanskim i kaznenim parnicama, a mogao je suditi i na smrt. Sve to obrazlažem primjerima i osudama.

5. Privreda u Varaždinu. Tu govorim o poljodjelstvu, obrtu i trgovini u starom gradu Varaždinu. Napose prikazujem život u Varaždinskim cehovima. Limitacija hrane, robe i plaća. Razvitak pomenutih putova u Varaždinu i oko njega. Mjere, vage i malte.

6. Financijalne prilike. Tu iznosim podatke o prihodu i rashodu grada Varaždina. Kako se nekada sklapahu zajmovi, dok još nije bilo štedionica. Nekadašnji novci, koji su kolali u Varaždinu. Osnutak i razvitak novčanih zavoda. Porezi i razne daće.

7. Socijalne prilike u starom Varaždinu. Tu govorim o žiteljstvu po staležima (plemstvo, građanstvo, kmetstvo). Bolesti, sprovodi i groblja. Bolnice, ubožnice i dobrotvorni zavodi. Gradski // noćibdija i strah od vatre. Loža slobodnih zidara u Varaždinu. Parnice proti vješticama.

Pripadom spominjem, da je taj drugi (posebni) dio varaždinske povijesti u glavnom već priređen za štampu. Za prvi sam dio (opća povijest grada Varaždina) prikupio sve potrebite podatke, koje sada sređujem za štampu. Nadam se, da ću tečajem naredne zime posve dovršiti i taj posao, pa to djelo predati slavnom gradskom načelstvu u Varaždinu.

Pitate me za »uslove«, uz koje sam pripravan to svoje djelo predati gradskom načelstvu. O tom ne postoji nikakav ugovor sa gradskim zastupstvom $u$ Varaždinu. Ja sam tada rekao, da ne tražim veći honorar, nego li ga daje »Matica Hrvatska«. To mi je usmeno i obećao tadašnji gradonačelnik. »Matica Hrvatska« plaća sada 800 dinara po štampanom arku srednjega (običnoga) formata, a 1000 dinara za štampani arak oveće osmine, kako bi trebalo da se štampa i povijest grada Varaždina. Držim, da će moje djelo iznositi oko 25 štampanih araka oveće osmine. Bude li toliko, tada sam ja za rad svaka od tih 25 godina zaslužio tisuću dinara, što zaista nije prevelika zarada.

Mislim, da sam time odgovorio na sva pitanja, koja mi je postavio g. senator Novaković kao vršilac dužnosti gradskog načelnika. Ujedno molim, da se to moje pismo iznese pred slavno gradsko zastupstvo, koje neka izvoli izreći svoju odluku, kako bi se i ja znao ravnati.

Izvolite, gospodine senatore, primiti izraz mog štovanja, kojim se bilježim.

dr. Rudolf Horvat

umirovljeni profesor

U Zagrebu, dne 24. kolovoza 1933.

Kačićeva ulica broj 20. 


\section{Odbor Matice?}

da se prihvati ponuda cijena prema ocjeni jurya Matice Hrv. osigura novac za Varaždin 26/VIII 1933

Prosvjetnom odboru ovdje na pretres.

v. d. gradonačelnik [potpisani] ${ }^{87}$

Horvat je ispravio godinu ugovaranja sastava povjesnice, obrazložio da mu je zbog ozbiljnijega istraživanja u arhivima trebalo desetljeća da je (na)piše, izjasnio se da nije tražio niti dobio predujam za pisanje povjesnice, da je iznos od 200 Kruna (sic!) dobio za istraživanje $u$ arhivima, ponovno se obranio da je vratio posuđenu građu. Iznio je kazalo rukopisa: I. dio čini opća ili politička povijest grada Varaždina (»kronika ili slijedored događaja«), a II. dio, posebnu povijest čini sedam tematskih poglavlja: crkva, školstvo, gradsko poglavarstvo, sudstvo, privreda, financijske i socijalne prilike. Iako je prepisao veći dio materijala, za tisak je pripremio dio monografije. Izrazio je da mu se za višegodišnji rad isplati 25.000 Dinara, tj. visinu honorara kakvu autorima isplaćuje Matica hrvatska. Rukopis je, između ostalih, pogledao i Kropek.

O rukopisu se raspravljalo na sjednicama Prosvjetnog odbora 26. rujna 1933. godine i Gradskog poglavarstva Varaždina 6. listopada 1933. godine. Na potnjoj sjednici bili su prisutni predsjedavajući, gradonačelnik Novaković, te 23-roje prisutnih i 7-ero »neisprićano otsutnih« zastupnika. Među prisutnima su bili Varaždinci svestranog obrazovanja i djelatnosti, javni bilježnici dr. Oskar Pulgram i dr. August Engelhardt, odvjetnik dr. Dragutin Vračun, sudbeni vijećnik Vlado Pongračić, »sreski školski nadzornik « Matko Rubinić, »posjednik i gostioničar« Tomo Lukinić, arhitekt Valent Morandini i soboslikarski obrtnik Josip Mišćin. ${ }^{8}$ Prisutni su donijeli odluku da se Horvatovo kolovoško pismo stavi u zapisnik sjednice. Iako prepisano od »Ad. I.)« s pravopisnim razlikama i netočnim podatkom da je Horvat na povjesnici počeo raditi u dobi od 30 godina, zapisana je odluka prisutnih:

87 DAVŽ, [0649] GPV, Korespondencija GPV i RH, pismo Rudolfa Horvata 24. kolovoza 1933., 13935/1933.

88 Gradonačelnik i navedeni zastupnici bili su članovi mjesnog odbora Jugoslavenske nacionalne seljačke demokracije 1932. godine, gradonačelnik je bio predsjednik, Mišćin prvi potpredsjednik, Pongračić tajnik, a Vračun, Engelhardt, Pulgram i Morandini članovi odbora. Vidi: HUZJAN, 2017., 108., bilješka 365.; O Rubiniću i Lukiniću: s. a., »Novo gradsko zastupstvo«, Varaždinske novosti, 2. srpnja 1931., br. 82, 1. 
Točka 10 broj 13.935/1933.

Gradsko načelstvo izvješćuje, da je u vezi svojedobnih pregovora iz godine 1909 stavilo upit na gosp. profesora Dra Rudolfa Horvat, dali je pribrao podatke za sastav povijesti grada Varaždina koji bi opseg i sadržaj bio te uz koje bi uvjete predao rukopis u vlasnost ovogradskoj općini. //

Prof. Dr. Horvat dostavio je slijedeći odgovor:

[...prijepis dijela Horvatova kolovoškog pisma...]

Načelstvo je mijenja, da je uvaženjem, što grad Varaždin neima zapravo pisane svoje povijesti osim fragmenata po Dru Ebneru i profesoru Jankoviću - kulturna potreba, da se povijest grada Varaždina napiše i rukopis postane kao vlasništvo ovogradske općine u svrhu slobodne štampe.

Mnijenja je, da se taj rad povjeri gosp. dru Rudolfu Horvatu uvaženjem već ranijih pregovora i njegova tom sastavu predhodećeg rada, nu drži da je honorar previsok, pa bi se poveli // pregovori za reduciranje.

Odbor predlaže, da se usvoji potrebna sastava

$1 /$ i edicije povijest grada Varaždina,

2/ da se sastav povjeri g. profesoru Dru Rudolfu Horvat u Zagrebu.

3/ da rukopis bude vlasnost gradske općine, koja bi to djelo izdala u ukusnoj opremi kolorirano sa slikama iz grada te prodajom primjeraka naplatila dio izdataka.

4/ da se o honoraru postigne sporazum, jer je zahtjev gledom na postoječe financijske prilike visok, u niječnom slučaju, da se honorar utvrdi prema ocjeni rada po jury-u Matice Hrvatske.

Zastupstvo prihvaća jednoglasno po predlogu odbora. $[\ldots]^{89}$

Preporuku o prihvatu visine honorara gradonačelnik je očito revidirao. Točka sjednice je sačuvana u strojopisnim prijepisima: prvi ima krivo pretipkani naziv dijela rukopisa »Sokolstvo u Varaždinu«, što je u drugom rukom ispravljeno $\mathrm{u}$ »Školstvo u Varaždinu «. ${ }^{90}$ Prosvjetni odbor planirao je smanjiti honorar, pa je gradonačelnik sročio predložak četiriju pisama, dva Horvatu, jedan Matici hrvatskoj i jedan Gradu Karlovcu:

< Na načełnikovom bijelom papiru >

Broj 17083/933. Vždin ${ }^{12} /$ xI $_{1933}$

Gospodinu D ${ }^{\text {ru }}$ Rudolfu Horvat

89 DAVŽ, [0649] GPV - Varaždin (1918.-1941.), Zapisnici skupština Gradskog zastupstva, Gradskog vijeća 1919.-1941., Zapisnik za 1933. godinu, sjednica 6. listopada 1933., 45-52.

90 DAVŽ, [0649] GPV, Korespondencija GPV i RH, strojopisne kopije, vezane za spis 17803/1933. 
Profesoru ?ps. Zagreb / Kačićeva ul. 20

Mnogo poštovani profesore profesore!

Vaše cjenjeno pismo od 24. kolovoza 1933. izneseno je u skupštini gradskog zastupstva na 6. oktobra tg., koje je zas stvorilo sljedeći zaključak:

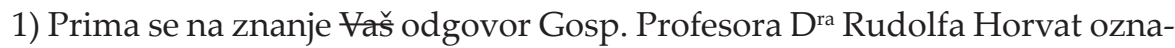
čen pod točkom 1.2. u pravcu svojedobnih odgovora oko I. sastava povijesti grada Varaždina s predstavnicima Grada, te odaje puno priznanje na brizi - trudu i stručnoj spremi oko sastava pribiranja podataka za tu povjest.

2) Objašnjenje točkom I-3 prima se jednoglasno na znanje i time objrakticifira u zabilješci praesidialnoj stavka o isplaćenoj // svoti od 200 Kr. oko predujma za tu povjest.

3) Odgovor - pod točkom I-4 o arhivskom materijalu - prima se na znanje i konstatira na zabilješci o svojedobno priposlanim arhivskim spisima time, da ovogradska općina podaje punu vjeru u navod Gospodina profesora $D^{\text {ra }}$ Rudolfa Horvat i ne želi nikakvih daljnjih izvidjaja

Ad II. Ovogradsko zastupstvo jednoglasno trvaja predloženisadržajrazdjel= ba zaključuje da se sastav povijesti grada Varaždina pregovorima povjeri profesoru g. Dru Rudolfu Horvat i usvoji po njemu predloženi sadržaj razdjelba i redosljed i da to djelo sa pi???? utvrđenim slikama o svom trošku izda općina grada Varaždina tečajem godine 1934 - uz uvjet da se poluči sporazum o honoraru. Kako su xxxxxxx znatno skučeni prihodi grada Varaždina u postojećoj ekonomsko-financijskoj krizi pa i iz drugih nepredviđenih razlog :(agrarna reforma - skučena vojna ki?ija itd.:) njegova financijska snaga znatno oslabljena, a uz honorar sastavljaču biće oveći // troškovi tiska kog itd to ima načelstvo o samom honoraru sa gosp. D ${ }^{\text {rom }}$ Horvat pokušati uglaviti reduciranu cijenu istu osigurati proačunom za godinu 1934.-

III < Na načelničkom papiru > Poštovani gospodine profesore dostavljajne ostavljam Vam gornji zaključak i molim Vas, da bi ste izvolili na isti svoju konačnu odluku priopćiti.

Iz Vašeg odgovora od-24-avgusta opažam Vaše negodovanje zbog sastava pojedinih točaka dostavljenog Vam pisma od 17. oktobra tg. pod brojem 13097 pa sam u tom pravcu slobodan dati slijedeće objašnjenje:

Kao rodjen Varaždinac i činovnik ovog historijskog grada vratih se sa ratišta i opazio sam u raznim prigodama da manjka gradu toli potrebna knjiga njegova povijest. Upućen, da je u tom predmetu Vama povjeren taj sastav listao sam praesidijalne zapisnike akte i našao tek nedostatno tek neke zabilješke iz kojih sam isk mogao zaključitł izveo sastav priposlanog Vam dopisa, kod čega mi je daleko strano, da Vam lično nanesem bilokakvu primjedbu. // Dopuštam, da su neka lica iznosila netočne podatke, no 
nisam tom poklonio vjere ni pažnje. ,niti Primio Vaš odgovor ,- lično sam ispitao predmet te ram je zastupstvo po mom referatu iznijelo priložen zaključak. Molim Vas stog Gospodine profesore da izvolite to objašnjenje primiti na znanje, pa mi u praveu kao i okasan odgovor na Vaš cj. list jer t aug u augustu i septembru nisu održane skupštine gradskog zastupstva.

Izvolite tom zgodom Gospodine profesore primiti uvjerenje mog poštovanja, [potpis]

III. Uredništvu Matice Hrvatske Zagreb

Umoljava se ugledni naslov, da bi izvolio priopćiti koji honorar plaća Matica po štampanom velikom arku piscima povijesnih sadržaja. [potpis]

[dopisano:] odg. 21/XI 33. [potpis]

IV. Iznesi broj: 17803 na broj 85/Pres 1933.

V. Gradskom načelstvu Karlovac.

Umoljava se naslov za diskretno saopćenje koji je honorar votirao piscu za svoj »Almanah grada Karlovca«i koji su troškovi tiska i klišeja. Ovom je načelstvo to potrebno radi predstojećeg izdanja povijesti grada Varaždina. [potpis]

pc- $15 /$ XII $933{ }^{91}$

U predlošku prvim dvama pismima upućenim Horvatu, gradonačelnik je primio na znanje Horvatov navod o predujmu od 200 Kruna (ali bez opaske da je svota namijenjena istraživanju) i navod da je gradskoj vlasti vratio sav »sporni« posuđeni arhivski materijal, te mu je napisao da će se rukopis s predloženim kazalom tiskati 1934. godine i da će mu se isplatit manji honorar u skladu s tadašnjim ekonomskim i financijskim uvjetima. Iz predloška drugog pisma naslućuje se da bi gradonačelnik mogao biti upravo pisac »Referata«.

Prema predlošku trećeg pisma, na gradonačelnikov upit Matica hrvatska je 25. studenog poslala osam primjeraka Horvatove knjige Hrvatska Podravina poprativši ih odgovorom: »[...] da Matica hrvatska plaća originalne radove, beletrističke ili poučne, sa Din. 800.- po arku/ format Matičinih redovnih izdanja/,a već štampana djela plaća sa jednom trećinom manje, t. j. plaća sa dvije trećine cijelog honorara. Veće formate preračunava prema broju redaka i slova manjega formata «. ${ }^{92}$ Četvrta točka donosi predložak upita Gradu Karlovcu o troškovima sastava karlovačke povjesnice. Na strojopisni upit od 21. studenog, četiri dana poslije, karlovački gradonačelnik je naveo: »Trošak tiska za 600 komada tvrdo u platnene korice uvezanih Almanaha grada Karlovca iznaša Din. 36.000.-, a klišeji u njemu otisnuti iznačaju cirka Din. 5.000.-«, te je pismo završio preporukom:

91 DAVŽ, [0649] GPV, Korespondencija GPV i RH, 17803/1933.

92 DAVŽ, [0649] GPV, Korespondencija GPV i RH, 20243/1933. 
»Inače je tiskara Gaj u Zagrebu veoma solidno izradila pomenutu knjigu i može se preporučiti «. ${ }^{93}$

Izgleda da su karlovački oci javili zagrebačkoj Štampariji »Gaj« o tom upitu, jer je na varaždinsku adresu 7. prosinca stigla molba kojom se Štamparija »Gaj« preporučuje za tisak povjesnice. ${ }^{94} \mathrm{Na}$ njezinoj je poleđini gradonačelnik 10. prosinca sročio predložak dvaju pisama. U prvom je odgovorio tiskari da dostavi ponudu za tisak »cca 30 štampanih araka oveće osmine i to u 500 primjeraka tvrdo uvezeno u platno«, koji će imati i »klišeje mjesnih-društvenih i reklamnih slika«. U drugom je upit s pitanjem o cijeni »luksuznog veza u koži za kojih 100 primjeraka « uputio Tipografiji Zagreb, Zakladi tiskare Narodne novine i Jugoštampi d.d, tražeći odgovor do kraja prosinca. Neobičan je spomen da bi tiskanu povjesnicu obogaćivali klišeji, tj. fotografije. Gradonačelnik je, želeći prikazati tadašnji društveni život, ispisao poziv varaždinskim društvima da »almanah « o vlastitom trošku obogate »historijatom« društava i klišejima, koje mogu poslati Gradskom poglavarstvu, u roku od mjesec dana, do 15. siječnja 1934. godine. ${ }^{95}$

Krajem prosinca i početkom siječnja stigle su ponude tiskara. Za posao su se 28. prosinca 1933. godine preporučile Zaklada tiskare Narodnih novina, ${ }^{96}$ Jugoslavenska štampa d.d., ${ }^{97}$ koje su poslale ogledne uzorke papira, dok Tipografija Zagreb nije mogla na sebe preuzeti obavezu tiska povjesnice zbog nedostatne naklade. ${ }^{98}$ Štampar Ljudevit Filigranić je dopisom 30. prosinca obavijestio da je Štamparija »Gaj« spremna za tisak i da je, u slučaju tog dogovora, on spreman pohoditi gradonačelnika na »dan u koje bi mu on volio odrediti, a posebno ako bi to bio blagdan ili nedjelja «. ${ }^{99}$ Štampar je poslao i ponudu za tisak rukopisa od 30 araka po 16 stranica u 500 primjeraka tvrdo, u platnu uvezene spomenice s papirom i formatom po uzoru na karlovačku povjesnicu, što bi iznosilo 67.500 Dinara.

Na poleđini tiskanice, gradonačelnik je uputio prijedlog Prosvjetnom odboru da se za »namaknuća sredstva i provedbe daljnjih odluka« o povjesnici izabe-

93 DAVŽ, [0649] GPV, Korespondencija GPV i RH, 85/Pres 1933, vezan za nadređeni spis 17803/1933.

94 DAVŽ, [0649] GPV, Korespondencija GPV i RH, 20593/1933.

95 DAVŽ, [0649] GPV, Korespondencija GPV i RH, V. prilog, datiran 15. prosinca 1933. vezan za spis 20593/ 1933. Sadrži historijate Crkvenog pjevačkog društva »Sv. Nikola«, Hrvatskog radničkog pjevačkog društva »Vijenac«, Udruge Sv. Antuna za pogrebnu pripomoć službenika stanice državne željeznice Varaždin, Podružnice Hrvatskog kulturnog društva »Napredak «, »Varaždinskih Hrvatica«, Radničkog naobrazbenog društva »Sloboda«, Jevrejskog društva, Varaždinskog biciklističkog kluba, Jugoslavenske matice podružnice u Varaždinu, »Hrvatskog Radiše « podružnica u Varaždinu, Francuskog kluba, Zanatlijskog i pomoćničkog društva.

96 DAVŽ, [0649] GPV, Korespondencija GPV i RH, 21717/1933.

97 DAVŽ, [0649] GPV, Korespondencija GPV i RH, 36/1934.

98 DAVŽ, [0649] GPV, Korespondencija GPV i RH, 106/1934.

99 DAVŽ, [0649] GPV, Korespondencija GPV i RH, 20593/1933. 
re uži odbor sastavljen od jednakog broja gradskih zastupnika i ne-zastupnika, građana. ${ }^{100}$ Odabrao je zastupnike Pulgrama, Engelhardta, Vračuna, Pongračića, Rubinića, Morandinija i Miščina, dok je Josipa Defranceskog pridružio petorici izvanrednih (ne)zastupnika, poznatih Varaždinaca, aktivnih u kulturnom i društvenom životu Varaždina. U odbor ih se predložio, sigurno, zbog njihova senzibiliteta koji su s obzirom na obrazovanje i široku djelatnost, imali za povijest grada. To su bili gimnazijski profesori - povjesničari Adolf Wissert i osnivač Gradskog muzeja Varaždin Krešimir Filić, te tadašnji ravnatelj gimnazije, likovni pedagog Lujo Pihler, i njima pridruženi ljekarnik i istraživač povijesti ljekarništva dr. Artur Krajanski i odvjetnik dr. Nikola Pečornik. Meki papir tiskanice i izblijedjelo olokvom pisano ime otežavaju čitanje imena zadnje, četrnaeste osobe koju je gradonačelnik predvidio za odbor, ali naknadno precrtao, odajući njegovu namjeru da odbor čini jednaki broj zastupnika i građana.

Siječanjskim pismom Horvat je javio gradonačelniku koje je tematske cjeline, dijelove rukopisa dovršio za tisak, odnosno, što može predati:

U Zagrebu, dne 10. siječnja 1934.

Visoko cijenjeni gospodine!

Čim sam od Vas primio obavijest, da će grad Varaždin g. 1934. štampati moju povijest, odmah sam počeo priredjivati rukopis za štampu. Do sada je već posve gotova jedna polovica, a drugu ću polovicu - nadam se - dovršiti do 1. lipnja 1934.

Svršio sam ova poglavlja: 1.) Povijest gradske uprave u Varaždinu. 2.) Sudbenost u starom Varaždinu. 3.) Promet i trgovina. 4.) Obrtnici i radnici. 5.) Socijalne prilike. 6.) Financijalne prilike u starom Varaždinu. 7.) Samostani i njihove crkve. 8.) Varaždinska društva. 9.)

Imam spremljen sav historijski materijal, koji sada sredjujem za tisak: 1.) Varaždinske župe (napose povijest župne crkve, te kapele sv. Visa, sv. Florijana, sv. Roka i sv. Fabijana i Sebastijana. 2.) Varaždinske škole (gimnazija, nekadašnja realka, više djevojačke škole, bivša trgovačka škola, te varaždinska pučka škola, počevši od 16. vijeka). 3.) Inevjerci (Židovi, protestanti i pravoslavci). 4.) Opća povijest grada // Varaždina podijeljena na ova poglavlja: 1.) Varaždin u srednjem vijeku. 2.) Varaždin u 16. vijeku. 3.) Varaždin u 17. vijeku. 4.) Varaždin u 18. vijeku. 5.) Varaždin u 19. vijeku i 6.) Varaždin u 20. vijeku.

Kada nešto popusti zima, doći ću u Varaždin na nekoliko dana, da se s Vama sporazumim glede samog štampanja povijesti slob. i kr. grada Varaž-

100 DAVŽ, [0649] GPV, Korespondencija GPV i RH, 167/1934. 
dina. Tom ću Vam prigodom reći svoje mnijenje glede slika, koje bi imale doći u knjigu. Sa sobom ću donijeti rukopis, koji ću dotle spremiti, da uzmognete pregledati moj rad. Izvolite primiti hrvatski pozdrav, što Vam ga od srca šalje iskreni Vaš štovatelj

dr. Rudolf Horvat

Kačićeva ulica broj 20

[četvrta stranica] Primio ${ }^{12 / 1}$ 934. K broju 167/934. [potpis] / Dužnosti iskaza vrela ${ }^{101}$

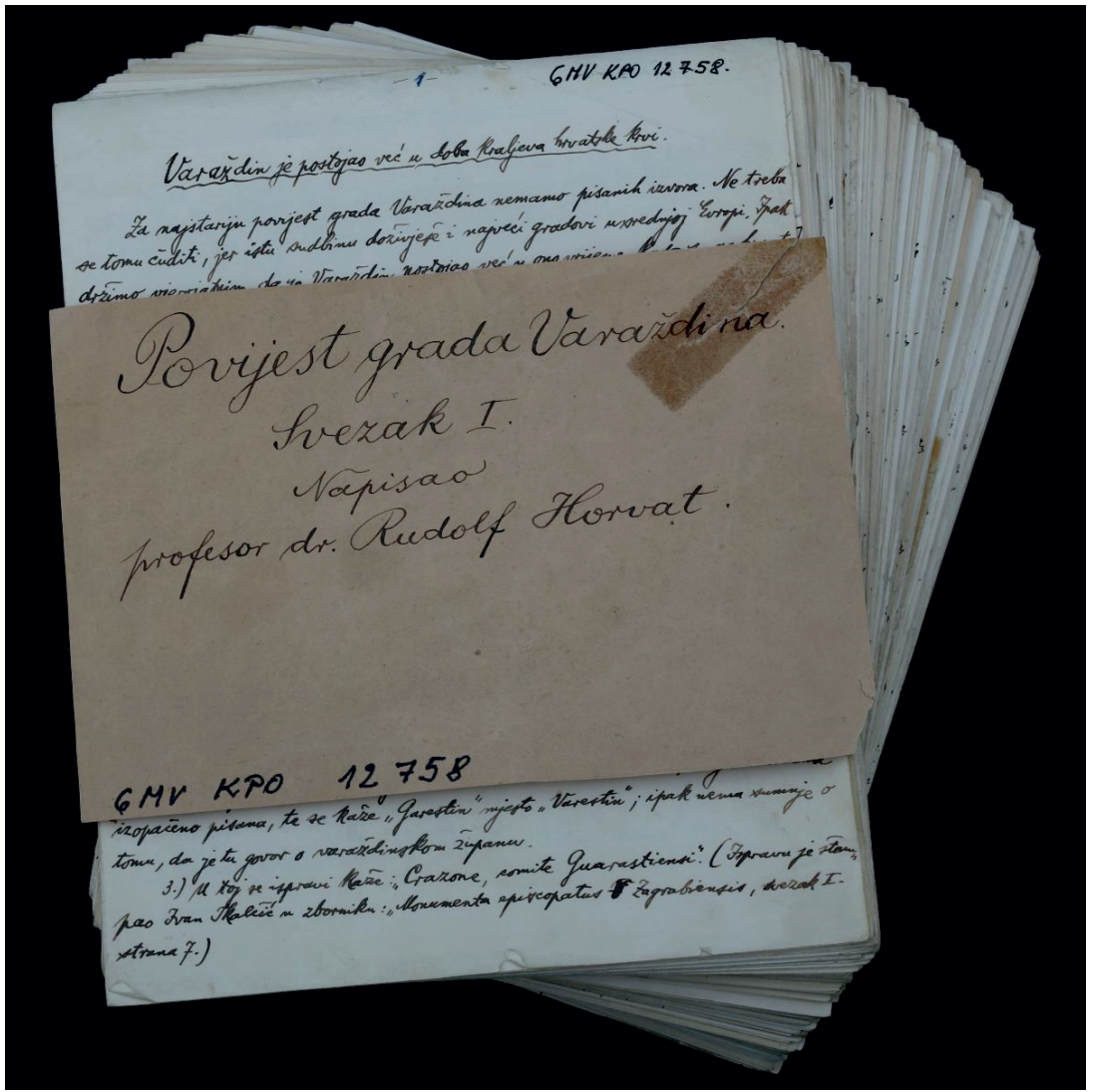

Slika 1. Rudolf Horvat, Povijest grada Varaždina. Svezak I. Napisao profesor dr. Rudolf Horvat, 1939., rukopis (tinta) i strojopis na papiru, $21 \times 17 \mathrm{~cm}$, 706 listova, Gradski muzej Varaždin (foto: Andrej Švoger, GMV).

101 DAVŽ, [0649] GPV, Korespondencija GPV i RH, pismo Rudolfa Horvata 10. siječnja 1934., uz spis $167 / 1934$. 
Ostala obrađena, za tisak nesređena tematska poglavlja namjeravao je do ljeta predati skupa sa sakupljenim, nesređenim materijalom za I. dio knjige koji je podijelio u poglavlja, prema vijeku u kojemu su se događaji zbivali. Čini se da nije prihvatio predloženi niži honorar jer je dolazak u Varaždin želio iskoristiti za dogovor o tisku. Prvog dana ožujka 1934. godine Štamparija »Gaj« je od gradonačelnika dopisom tražila potvrdu primitka na njezin predračun i kalikl koji mu je poslala krajem prosinca. ${ }^{102}$

Tijekom 1934. i idućih godina na skupštinama se najviše raspravljalo o honoraru. Svega sedam dana nakon što ga je Novaković primio, o Horvatovom siječanjskom pismu Gradsko poglavarstvo Varaždin je raspravljalo 19. siječnja. Na sjednici su 25-orica zastupnika, među njima javni bilježnici, odvjetnik, sudski vijećnik, sreski nadzornik, arhitekt i soboslikar (gostioničar je bio »neisprićano otsutan«), uz gradonačelnika, jednoglasno usvojili:

Točka 6. broj 167/1934.

V. d. gradonačelnik Novaković Stjepan izvješćuje, da je zaključak // zastupstva od 6/X 1933 član 69 točka 10 broj 13.835 u predmetu sastava povijesti Varaždina dostavio Dr. Rudolfu Horvatu kao odgovor na njegovo pismo od 24/VIII 1933 i tražio mišljenje honorara za sastav jer je nagrada od 25.000 za taj sastav za današnje prilike preskupa. Dr. Horvat odgovorio je pismom od 10/I 1934 da će sastav dovršiti u polovini ove godine i skoro osobno pridoći na dogovor glede cijene i sadržaja. Istodobno pisao sam na 1/ Štampariju Gaj i 2/ Tipografiju 3/ Jugoslavensku štampu 4/ Tiskaru Narodne Novine, za informaciju za tisak oko 500 primjeraka povijesti sa 400 stranica oko 67.000. din. bez klišeja. A mijenja sam da bi se rasprodalo do 300 primjerka po din.100-30.00 din. da bi se sabiranjem pripomoći i odštete na klišejima i reklamama dobilo oko din. 30.000.- preostao bi još trošak oko din. 25.000.- nepokriven. Odbor predlaže, da se sa Drm Rudolvom Horvat utvrdi sadržaj i cijena - dobave još potrebni podaci o pokriću troškova izdanja - a po tom izabere poseban odbor, koji će rukovoditi tim poslom, pa ne bude li pokrića odgodi predmet za narednu godinu.

U taj odbor izabrani su predlažu se sl. iz gr. zastupstva: Pongračić Vladoj, Morandini Valent, Dr. Vračun Drag, Dr. Pulgram Oskar, Rubinić Matko, Dr. Engelhardt, Mišćin Josip, a iz gradjanstva: Filić Krešimir, Dr. Pečornik Nikola, Wissert Adolf, Pichler Lujo, Dr. A. Krajanski, Josip Defranceski. / Zastupstvo prihvaća jednoglasno po predlogu odbora. [...] $]^{103}$

102 DAVŽ, [0649] GPV, Korespondencija GPV i RH, neurudžbiran dopis Štamparije »Gaj«, 1. ožujka 1934.

103 Na točku upućuje zapis u kazalu Izvješće gradonačelnika o predmetu sastava povijesti grada Varaždina po Dru. Rudolfu Horvatu, DAVŽ, [0649] GPV - Varaždin (1918.-1941.), Zapisnici skupština Grad- 
Potvrđuje se tijek komunikacije između gradonačelnika i povjesničara, gradonačelnika i odborā, te gradonačelnika i tiskarā. U toj točki gradonačelnik je sažeo dotadašnji napor svih strana na izradi povjesnice i potvrdio članove trinaesteročlanog odbora. Ističe se gradonačelnikov stav da bi se trošak tiskanja mogao umanjiti dobrovoljnim prilozima, što se najvjerojatnije odnosi na iznos koji bi varaždinska društva dala kako bi se u povjesnici tiskale fotografije njihovih članova ili odbora, i njihove reklame.

Strojopisna kopija zaključene točke ove sjednice poslužila je gradonačelniku da dva i pol mjeseca poslije, 5. ožujka, na poleđini ispiše obavijest tiskarama o odgodi tiska, a na prvoj strani obavijest Horvatu o zaključcima sjednice:

Vždin $5 /$ III 1934

Grad Varaždin grad. štamp izdanje povijesti grada

1) Pn Zakladi tiskare Narodnih novina Zgb, Frankopanska 16

2) P. t. Jugoslavenska štampa d. d., Masarykova 28 Zagreb

3) P. t. Štamparija Gaj, Zagreb Palača burze

U vezi ovostranog raspisa od: 10. decembra 1933 broj 20.593 na pozvani na tamošnju cijenjenu ponudu za štampanje Povijesti grada Vždina, čast mi je izvijestiti ugledni / naslov, da je sastavljač gradiva povijesti uslijed naknadno najavio, da će svoj rukopis dovršiti tek oko u mjesecu lipnju t.g. Kako sam sadržaj nije po tom još radigo?? ni ocjenjen, a prema tom ni stalno utvrdjen opseg formata, to je odgodjena odluka o samom izboru tvrdke i formi štampanja te sastavljač pozvan da predloži bar svoj dosadanji izradjen rad. Gradskom odboru na dalnje proučenje i odluku - čim to stiže rešiće se i predložene ponude, te ob uspjehu naslov izvijestiti. [potpis]

< Na načelničkom papiru >

Vždin $5 /$ III 934 .

Visko cj. Gospodine profesore!

Na vaše cijenjeno pismo od 10/I 1934, a u vezi ovostranog rješenja broj 17803 od $12 /$ XI 1933. pošto nisam mogao lično da raspravljam s Vama još viseća pitanja o samom sastavu povjesti, a napose honoraru, čast mi je umoliti Vas za obavijest prema spomenutom rješenju odluke // koliki će konačno opseg imati sam sastav povjest grada i koji je neodstupni vaš honorar i može li rukopis rada dobiti odbor na pregled. Izvoljnog znanja

skog zastupstva, Gradskog vijeća 1919.-1941., Zapisnik za 1934. godinu, sjednica 19. siječnja 1934., 34-35. 
radi načelstvo bi samo sastavilo i priložilo odlomak o sadanjim društvima - privredi te socijalno-zdravstvenim i financijskim prilikama. Čast mi je stog To je potrebno u svrhu da odbor konačno i obvezatno odluči o tom predmetu te osigura sredstva za honorar i štampu, odnosno da uloži cio predmet na kasnije pogodrješenje.

$\mathrm{PC}-2 / \mathrm{IV} 934 .{ }^{104}$

Gradonačelnik je žalio što o pitanjima oko rukopisa nije mogao raspravljati s Horvatom, pretpostavlja se, prilikom posjete povjesničaru u Zagrebu. Ovdje je, čini se, prvi puta javio povjesničaru da će se povjesnica obogatiti »odlomkom«s historijatima društava, te ga je ponovno tražio mišljenje o visini honorara.

Pišući pismo gradonačelniku krajem ožujka, Horvat je ustrajao na prvotnom honoraru te je molio da mu se pri predaji dijela rukopisa isplati jedan dio honorara, a drugi po predaji preostalog dijela. Čini se da je gradonačelnik ranije posjetio Horvata u Zagrebu i da se Horvat složio s tiskom »almanaha" uz povijesnicu. Izgleda da je, što se iz siječanjskog povjesničareva pisma naslućuje, Horvat prije ovog »ožujskog " pisma bio, nesumnjivo, obaviješten o formiranom odboru koji će rukopis ocjenjivati:

\section{Magnifice domine!}

Meni je neizrecivo žao, što nijesam bio kod kuće, kada ste me počastili svojim posjetom. Da sam znao za Vaš dolazak, radosno bih Vas dočekao, jer iskreno želim, da se s Vama što prije lično upoznam i porazgovaram. Nadam se, da ću to naskoro i polučiti, jer oko 20. travnja namjeravam poći u Varaždin i ondje ostati nekoliko dana.

Na Vaše cijenjeno pismo odgovaram Vam ovo: 1.) Kako Vam već svojedobno izvjestih, moja će »Povijest Varaždina« zapremati 25 štampanih araka ovećega formata. 2.) U ime honorara molim onoliko, koliko plaća »Matica Hrvatska«. Isto toliko plaća i društvo sv. Jeronima. Taj honorar iznosi 800 dinara po štampanom arku oveće osmine (oktav format), a 1000 dinara za arak oveće osmine, kako bi trebalo štampati »Povijest Varaždina « s obzirom na slike. 3.) Glede isplate honorara molim, da mi se honorar za prvih 10 araka dade onda, kada gradu predam rukopis, a ostatak onda, kada bude odštampana cijela knjiga. //

Kada dodjem u Varaždin, ponijet ću sa sobom ovaj dio rukopisa, koji će dotle biti dovršen. Uljudno molim, da blagoizvolite odrediti (odnosno udesiti) sastanak onog odbora, kojim je gradsko zastupstvo povjerilo pregled mog rukopisa.

104 DAVŽ, [0649] GPV, Korespondencija GPV i RH, 2096/1934. 
Uzimam na znanje, da »vamo načelstvo«, pod kojim razumijevam Vašu vrijednu osobu, želi sastaviti i mojoj povijesti Varaždina »priložiti odlomak o sadašnjim društvima i privredi, te o socijalnim, zdravstvenim i financijskim prilikama«. Taj dodatak dobro će čitatelju poslužiti iza mojeg pripovijedanja o prošlosti takovih uredaba u gradu Varaždinu.

Dozvolite, gospodine gradonačelniče, da Vam zaželim sretne uskrsne blagdane. Podjedno se bilježim s iskrenim pozdravom i duboko osjećajnim štovanjem.

dr. Rudolf Horvat

U Zagrebu, dne 29. ožujka 1934.

Kačićeva ulica broj $2 .^{105}$

Početkom travanja gradonačelnik je Horvatu ponovno prenio razloge zbog kojih poseban odbor ne može prihvatiti predloženi honorar:

Vždin $\%$ IV 1934

$<$ Na načelničkom papiru >

Adresa

Gospodinu

Dru Rudolfu Horvat / profesoru / Zagreb / Kačićeva ul 20

Veleučeni Gospodine!

Primio sam Vaše cjenjeno pismo od 29 na 3-0 o. mj. pa Vam hvalim za lične želje i jednako uzvraćam.

U poslu sastavka povijesti grada Varaždina mislim kako sam već i izvjestio da traženi honorar prelazi predviđen proračun / odbora za sastav povijesti grada Varaždina i dvojim da će ga u toj visini odbor moći prihvatiti jer su financijske prilike grada zbog Varaždina kao i općenito znatno oslabile.

Kako u Prema Vašoj obavjesti ostajete u Varaždinu više dana, a po tom neće biti odlučno da 20 aprila neću biti u Varaždinu, već tek 21. aprila tg.

Posljednji puta zadržao sam se dugo na Banskoj upravi pa sam umalo okasno stigao do Vas, da lično s Vama o tom predmetu porazgovorim.

Izvolite Veleučeni Gospodine primiti istom uvjerenje mog osobnog poštovanja [potpis]

Sc $-{ }^{20}$ IV 1934106

105 DAVŽ, [0649] GPV, Korespondencija GPV i RH, pismo Rudolfa Horvata, 19. ožujka 1934.

106 DAVŽ, [0649] GPV, Korespondencija GPV i RH, 6270/1934. 
Mjesec dana poslije 6. svibnja gradonačelnik je »Prosvjetnom odboru ovdje na znanje i pretres « uputio dopis bez navoda o predmetu. ${ }^{107}$ Najvjerojatnije se odnosio na spomenicu jer je idući dan ispisao pozivnicu svim članovima posebnog odbora kako bi, dolaskom na zabilježeno mjesto i vrijeme, 8. svibnja u 18 sati u gradskoj vijećnici ocijenili dio rukopisa koji je Horvat osobno donio. Pozivnica se sačuvala i u strojopisnoj inačici. ${ }^{108}$ Trinaestoeročlani odbor odluke je, izgleda, hitno prenio gradonačelniku koji je idući dan njihove zaključke proslijedio Prosvjetnom odboru. Tijekom trodnevne posjete Varaždinu Horvat je dalje ustrajao u visini honorara:

Broj 6270/934 Varaždin $9 / \mathrm{v} 934$

Predmet: Povijest grada Varaždina, sastav i izdanje

Prosvjetnom odboru grad. zastupstva Varaždin

Predlaže se cio predmet na dalnji pretres izvještajem da je Dr. Horvat dne 78 i 9 proveo u Varaždinu donio dio rukopisa povijesti obrazložio o cijelom rasporedu i sastavu dijela užem odboru na 8. tmj te obrekao, da će djelo do augusta tg. dovršiti. Savremeno stanje obradiće samo načelstvo. Ostaje kod zahtjeva honorara po 1000 Din po velikom tabaku arka, a njegov će rukopis iznijeti 25 tabaka. Rukopis ima ocijeniti poseban uži odbor i predložiti svoju ocjenu rada i mnijenje o honoraru koji bi se imao platiti po dovršenoj // ocjeni. Osim izdanja imade se provesti stvoriti plan o naplati troškova i raspačanjem i doprinosi dobrovljnih građana itd. Rukopis i cinkografija za 1000 kom iznijeće oko 100.000. Din. ${ }^{109}$

Svi ti gradonačelnikovi dopisi zavedeni su u kazalu općih spisa Gradskog poglavarstva za 1934. godinu. ${ }^{110}$ Posljednji gradonačelnikov dopis - izvještaj, bio je predmet rasprave Prosvjetnog odbora, čije su odluke prihvaćene na skupštini Gradskog poglavarstva Varaždin 25. svibnja 1934. godine. Između 24-orice zastupnika prisustvovali su spomenuti ugledni Varaždinci. Zaključili su da će se iz posebnog odbora odabrati četvero zastupnika koji će imati zadatak sniziti honorar i ocijeniti rukopis:

107 DAVŽ, [0649] GPV, Korespondencija GPV i RH, datiran 6. svibnja 1934.

108 DAVŽ, [0649] GPV, Korespondencija GPV i RH, 6270/1934, rukopis 7. svibnja 1934., strojopis 7. svibnja 1934.

109 DAVŽ, [0649] GPV, Korespondencija GPV i RH, 6270/1934, 9. svibnja 1934.

110 »Horvat Dr. Rudolf izvještaj o povijesti grada Varaždina. 6270«, Povijest grada Varaždina - izvještaj Dr. Horvat Rudolfa o dovršenju istog čl. 55 toč. 3. Broj 6270/34.«, DAVŽ, [0649] GPV - Varaždin (1918.-1941.), Kazala općih spisa 1918.-1941., Kazalo za 1933. godinu, s. p. 
Točka 3. broj 6270/1934.

Gradsko načelstvo izvješćuje, da je Dr. Horvat

[... nastavak iz gradonačelnikova izvješća 9. svibnja 1934....]

Odbor predlaže, da se izabere uži odbor za pregled rukopisa i to gg. Dr. Pulgram Oskar, Rubinić Matko te profesor g. Filić Krešimir Wissert Adolf. / Zastupstvo prihvaća jednoglasno po predlogu odbora. [...] ${ }^{111}$

Može se pretpostaviti da će zastupnici raspravljati o visini honorara, a profesori dati mišljenje o rukopisu. O tom ih je gradonačelnik obavijestio 18. lipnja. U toj namjeri, gradonačelnik je na strojopisnoj kopiji točke zaključka sjednice prvo ispravio krivi datum održavanja sjednice (25 marta 1934) i ispisao predložak poziva četveročlanom odboru, strojopisni poziv s njegovim imenom, prezimenom i zanimanjem. ${ }^{112}$ Dopisom od 5. rujna 1934. godine Štamparija »Gaj« opet je, poslavši ogledni primjerak spomenice Duge Rese, podsjetila da je spremna tiskati povjesnicu. ${ }^{113}$ Čini se da se gradonačelnik ponovno obratio Štampariji »Gaj«.

U zapisnicima sjednica za 1934. i 1935. godinu nema bilježaka o Horvatu i povjesnici te se ne može sa sigurnošću znati jesu li oci prihvatili traženi honorar ili su postigli drugi dogovor. Rasvjetljavanju tog pitanja pomaže dopis šefa gradskog računovodstva, kojim je 1. listopada 1935. godine od gradonačelnika tražio, to jest, dao mu je prijedlog isplate honorara:

Gradsko računovodstvo u Varaždinu.

Broj 2542/1935. u Varaždinu 1, X 1935.

Predmet: Spomenica i / povijest grada Varaždina.-

Gradskom poglavarstvu / Ovdje

Proračunom za god. 1935/36 osigurano je na partiji XV pozic. 6/2 u gornju svrhu D. 25.000- Neka naslov izvoli dati ovu svotu u 5 obroka realizirati iz grad. domaće blagajne i preuzeti među grad. pologe, a iz polog u gornju svhu dati ulagati u grad. štedionu kako nebi gradska općina kasnije dok će povjest biti dogotovljena bila u neprilici glede isplate honoraa.Šef grad. rač. [pečat, potpis] ${ }^{114}$

\footnotetext{
111 DAVŽ, [0649] GPV - Varaždin (1918.-1941.), Zapisnici skupština Gradskog zastupstva, Gradskog vijeća 1919.-1941., Zapisnik za 1934. godinu, sjednica 25. svibnja 1934., 51.

112 DAVŽ, [0649] GPV, Korespondencija GPV i RH, 10760/1934, kopija zaključka skupštinske sjednice 25. svibnja 1934.; DAVŽ, [0649] GPV, Korespondencija GPV i RH, 10760/1934., četiri strojopisa 18. lipnja 1934.

113 DAVŽ, [0649] GPV, Korespondencija GPV i RH, 15030/1934.

114 DAVŽ, [0649] GPV, Korespondencija GPV i RH, 17354/1935.
} 
Idući podatak o povjesnici čita se u prijedlogu proračuna grada Varaždina za 1936. godinu koji je prihvaćen na gradskoj sjednici 30. ožujka 1936. godine. U njemu, među Vanrednim rashodima stavka Ostale prosvjetne ustanove uključuje prvu podstavku, na poziciji 19, povijest grada Varaždina i spomenica 25.000.- Dinara. ${ }^{115} \mathrm{Je}$ li spomenica koja se tu navodi, kakva spomenica o kojoj se se pričalo 1909. godine? ${ }^{116}$ Dijelove rukopisa Horvat je u ljeto 1935. i 1936. godine predao zastupniku Novakoviću, koji ga je proslijedio novom gradonačelniku, dr. Vladimiru Milkoviću. Osim što nekadašnji gradonačelnik piše tadašnjem koje je točno sveske rukopisa preuzeo, on je 8. kolovoza 1936. godine dao, smatra se, prvu kritiku rukopisa:

\section{Gospodinu}

Dru Vladimiru Milković

predsjedniku grad. općine

Varaždin

U privoju ./. predajem Vašem Gospodstvu prošle godine preuzeti II svezak i dne 5. augusta I-V svezka rukopisa gradiva za povijest grada Varaždina predan po profesoru Dru Rudolfu Horvat iz Zagreba. Sastav povijesti po predatelju poručeno je još godine 1912 a obnovljen godine 1931 kako se to iz zaključka zastupstva i predspisa vidi.

Dr Horvat traži prema svojedobnom zahtjevu, da mu se svota od 10.000 Din isplati sada po predaju rukopisa a 15.000 Din kad će se dati u tisak. Ja sam mišljenja, da se rukopis da na ocjenu kojemu stručnjaku i prema uspjehu stavi u tisak ili posluži za gradivo povijesti grada // Varaždina po kojem mom stručnjaku.

Lično pročitao sam VI svezak (jer su mi ostali tek predani tek $5 /$ VIII tg.) i moram spomenuti da taj sastav nije za konačni tisak dotjeran, nije povijesno-književni osobit - a opaža se prečesta ponova nepotrebnih istovjetnih fragmenta.

Prvi dio Din 10.000 imalo bi se pritom odmah isplatiti, a u slučaju nepovoljne ocjene stručnjaka nastojati prekupiti rukopis pa ga po nahodenju predati na dovršenje mom stručnjaku.

Varaždin $8 /$ VIII 936.

Stjepan Novaković

115 DAVŽ, [0649] GPV - Varaždin (1918.-1941.), Zapisnici skupština Gradskog zastupstva, Gradskog vijeća 1919.-1941., Zapisnik za 1936. godinu, sjednica 30. ožujka 1936., prilog: prijedlog proračuna za 1936/37. god., 15 .

116 s. a., »K sedamstogodišnjici grada Varaždina. II.«, Naše pravice, 5. kolovoza 1909., br. 31, 3-4. 
Potvrdjujem primitak

šest svezaka gradiva

povjesti od g. Novaković

Stjepana gr. senatora $\mathrm{u} \mathrm{m}$.

Varaždin 8/VIII 1936

Habek Mirko [potpis] ${ }^{117}$

Novi gradonačelnik je 10. kolovoza dao uputu gradskoj blagajni da Horvatu isplati iznos od 10.000 Dinara za šest predanih svezaka, a ostatak nakon predaje preostalih dijelova. ${ }^{118}$ Krajem ožujka 1937. godine, Gradsko poglavarstvo Varaždin prihvatilo je proračun za godinu 1937/38., time i iznos od 20.000. Dinara Za povijest grada Varaždina i spomenicu, u prvoj podstavci stavke Prosvjeta, u Vanrednim rashodima. ${ }^{119}$ Ako se Horvatu trebalo isplatiti još 15.000 Dinara, za što je sve iznos bio namijenjen? Moguće da je, osim honorara, uključivao i trošak tiskanja jer je gradonačelnik dopisom računovodstvu 28. kolovoza 1937. godine predvidio trošak tiska »50-60.000 Dinara, a možda i više «. ${ }^{120}$

Posljednje, četvrto sačuvano pismo, Horvat je napisao u zimi 1938. godine. U njemu je »dragom prijatelju « zabilježio značajne trenutke oko dogovora i pisanja povjesnice, te izrazio zabrinutost hoće li mu honorar koji je dogovorio s nekadašnjim biti isplaćen prema dogovoru s novim gradonačelnikom. Taj »na čisto kulturni dio varaždinske povijesti«, koji je dovršio, vjerojatno se odnosi na ostala tematska poglavlja II. dijela rukopisa o kojima je pisao u prvom pismu, pet godina ranije.

U Zagrebu, dne 21. prosinca 1938.

Kačičeva ulica 20.

Carissime amice!

Tebi je poznato, da mi je gradsko zastupstvo u Varaždinu godine 1909. povjerilo pisanje povijesti grada Varaždina. Ja sam na tom djelu radio 27 godina, te sam rukopis predao g. 1936. u ruke tadašnjeg gradonačelnika g. dra. Vladimira Milkovića. Po ugovoru s prijašnjim gradonačelnikom g. Stjepanom Novakovićem imao sam dobiti honorar od 25.000 dinara. Kako do g. 1936 nije bio još posvema obradjen i na čisto prepisam kulturni dio

117 DAVŽ, [0649] GPV, Korespondencija GPV i RH, 13919/1936.

118 Ibidem.

119 DAVŽ, [0649] GPV - Varaždin (1918.-1941.), Zapisnici skupština Gradskog zastupstva, Gradskog vijeća 1919.-1941., Zapisnik za 1937. godinu, sjednica 30. ožujka 1937., prilog: prijedlog proračuna za 1937/38. god., s. p.

120 DAVŽ, [0649] GPV, Korespondencija GPV i RH, 12463/1937. 
varaždinke povijesti, doznačio mi je g dr. Milkovića samo 10.000 dinara. Ostatak od 15. dinara obećao mi je isplatiti onda, kada predam i kulturnu povijest grada Varaždina. O tom imam i pismeno rješenje, kojega se koncept nalazi i medju spisima grada Varaždina. //

Uljudno Ti javljam, da sam konačno dovršio i za tisak prepisao takodjer kulturnu povijest grada Varaždina. Ovaj svoj rukopis želim osobno donijeti u Varaždin i Tebi ga predati u četvrtak 29. prosinca. Rad bih se još istog dana vratiti u Zagreb. Zato Te molim, da mi na priloženoj dopisnici izvoliš napisati, da li ćeš Ti biti u Varaždinu 29. prosinca i da li mogu istog dana podići ostatak honorara u iznosu od 15.000 dinara.

Želim Ti čestit Božić, te se bilježim s hrvatskim pozdravom

stari Tvoj drug

dr. Rudolf Horvat ${ }^{121}$

Prva tri pisma Horvat je sa štovanjem uputio tadašnjemu gradonačelniku, kojega spominje u ovom pismu, pa Novaković nije njegov dragi prijatelj kojemu piše. Ton pisma upućuje na neku osobu blisku Horvatu, jer mu se bilježi kao stari njegov drug, s kojim je Horvat komunicirao u gradu Varaždinu i koji je bila upućen u tijek nastanka rukopisa.

Nedvoumice oko tiskanja povjesnice razrješuje knjiga zapisnika sjednicā skupštinā Gradskog poglavarstva Varaždin za 1940. godinu. Stavka kazala Horvat Rudolf, o povijesti grada Varaždina toč. 15 broj 6447/1939, str. 192., odnosi se na točku sjednice skupštine Prosvjetnog odbora 1939. godine koja se raspravljala na sjednici skupštine Gradskog poglavarstva Varaždin, 2. prosinca 1940. godine. Na sjednici su uz v. d. gradonačelnika Ljudevita Bana, prisustvovali i zastupnici tvorničar kišobrana Mijo Cepanec, liječnik dr. Velimir Kalafatić, odvjetnik dr. Slavko Medvedović i gradski vijećnik Mirko Hikec. ${ }^{122}$ Prisutni su odlučili:

\section{Točka 15 broj 6447/1939}

Poglavarstvo izvješćuje, da je prema svojedobnom zaključku i pogodbi općine sa našim historičarom g. Dr. Rudolfom Horvatom, gosp. Dr. Horvat prošle godine predao ostatak rukopisa njegove povijesti grada Varaždina, te mu je isplaćen cijeli pogodjeni honorar od 25.000 dinara za sastav povijesti našega grada, pa bi bilo potrebno, da se po gradskom zastupstvu izabere posebni uži odbor, koji bi imao pregledati rukopis te dati gradskom

121 DAVŽ, [0649] GPV, Korespondencija GPV i RH, pismo Rudolfa Horvata, 21. prosinca 1938. 
zastupstvu svoj prijedlog o načinu izdanja te povijesti štampom, i predložiti predračun troškova. / Odbor jednoglasno predlaže, da se prihvati ovaj prijedlog gradskog poglavarstva, te u uži odbor da se izaberu gradski zastupnici gg. Franjo Galinec, Dr. Medvedović Slavko, Dr. Kalafatić Velimir, a izvan kluba gradskog zastupstva gg. profesor Wiessert Adolf, profesor Filić Krešimir i ravnatelj škola Pihler Lujo, te gradski senator Hikec Mirko. // Gradsko zastupstvo prihvaća jednoglasno po prijedlogu odbora. [...] ${ }^{123}$

Horvat je čini se, ostatak rukopisa predao 1938. godine i tada mu je isplaćen preostali dio honorara. U svrhu pregleda rukopisa i poslova oko tiska formiran je sedmeročlani odbor: zastupnicima Galincu, Medvedoviću i Kalafatiću, te građanima Wissertu, Filiću i Pihleru pridružen je »ispričano odsutan« zastupnik, gimnazijski profesor Franjo Galinec. Pod urudžbenim brojem 6447/1940, za koji kazalo općih spisa navodi da se odnosi na rukopis, stoji račun »Tiskare Štifler vl. A. Šarec za tiskanice za grad. redarstvo « u iznosu od 280 Dinara, koji se tereti na budžet za 1940./1941. godinu. Pečaćena 27. travnja 1940. godine, na tiskanici ne piše što se njom plaća. ${ }^{124}$

Odluka o tisku povjesnice prethodila je odluci o tisku srednjovjekovnih isprava grada Varaždina od 1209. do 1526. godine, koji je predložio povjesničar i arhivist Hrvatskog državnog arhiva Zlatko Tanodi, o čemu su građani ubrzo doznali putem novina. ${ }^{125}$ Član sedmeročlanog odbora, Mirko Hikec se u pregovoru Tanodijeve knjige osvrnuo i na Horvatov rukopis istaknuvši da je rad na njegovom pisanju bio započet prije 30 godina i nedavno završen. ${ }^{126} \mathrm{Iz}$ ovih Hikecovih i Horvatovih riječi da je prije Prvog svjetskog rata veliki dio građe obradio (sic!) za tisak, možda se, unatoč Hikecovoj opasci o nedavnom završetku rukopisa, razvilo prihvaćeno mišljenje da je Horvat glavninu rukopisa napisao oko 1912. godine. Međutim, neosporno je da je Horvat dijelove rukopisa predao u nekoliko navrata, počev od 1934. godine.

\section{O RUKOPISU IZ POVJESNIČAREVA OSOBNOG FONDA}

Osobni fond Rudolfa Horvata u Hrvatskom državnom arhivu u Zagrebu sadrži podatke o rukopisu. Daju novo svjetlo na opomene gradske vlasti Horvatu da joj vrati svu posuđenu arhivsku građu. Osim što je građu proučavao u prisut-

123 DAVŽ, [0649] GPV - Varaždin (1918.-1941.), Zapisnici skupština Gradskog zastupstva, Gradskog vijeća 1919.-1941., Zapisnik za 1940. godinu, sjednica 2. prosinca 1940., 77-78 (192-193).

124 DAVŽ, [0649] GPV - Varaždin (1918.-1941.), Opći spisi 1918.-1940., 6447/1940.

125 s. a., »Sjednica plenuma gradskog zastupstva«, Hrvatsko jedinstvo, 7. prosinca 1940., br. 165, 3.

126 HIKEC, 1942., VII. 
nosti prof. Julija Jankovića, Horvat ju je istraživao i u gradskoj vijećnici. Tvrdnju potvrđuje sačuvani list papira koji je Horvat olovkom ispisao s podacima o trima protokolima u »arkivu grada Varaždina«: prvi »najveći« protokol, drugi »najmanji« (1646.-1674.) i treći »srednje veličine« (1686.-1703.). Bilješke je zaključio je najvećim slovima i crveno ispisanom opaskom: »Preostali protokoli grada Varaždina, / koji se nalaze u načelnikovom predsoblju / gdje je ormar s ispravama «. ${ }^{127}$ Je li moguće da ih je proučavao u vijećnici? Deseci listova na kojima je Horvat prepisivao podatke iz političkih, sjedničkih i sudskih zapisnika grada Varaždina pokazuju da je građu posudio za istraživanje u zagrebačkom arhivu. ${ }^{128}$

Horvat je povijest Varaždina istraživao i nakon 1912. godine. Na nekoliko listova papira gusto je ispisao podatke o povijesti grada za Prvog svjetskog rata preuzimajući ih iz varaždinskih novina Hrvatsko pravo (pet godišta, 1914.1918.). ${ }^{129}$ Na postojeće listove gusto ispisanih redova podatke je dopisivao i 1930ih godina: na listu Grad Varaždin ispisao je podatak o smrti nadrabina dr. Ignjata Ernsta 27. prosinca 1916. i olovkom dodao da mu je sin preminuo 1934. godine. ${ }^{130}$ U bilješci Moje radnje iz povijesti grada Varaždina - na dva lista papira tintom je ispisao naslove rukopisa i tiskanih radova o varaždinskoj povijesti, u zagradama naslov, godinu i broj godišnjaka, zbornika, časopisa i novina u kojima su objavljeni ili broj stranice izdanja na kojoj rad počinje. Među pedeset i sedam, nižu se i naslovi radova koje je objavio nakon 1912. godine, među njima i »Izbor i inštalacija varažd. sudaca u 18. v. (Novosti 19. pros. 1926.)«. Ispred naslova Horvat je olovkom doznačio + ili -, i značenje objasnio olovkom uz gornji rub papira: »označeno sa - nijesu prepisane, a sa + već su prepisane na čisto za tisak «. ${ }^{131}$ Plava omotnica olovkom ispisanim naslovom »Varaždin u 20. vijeku«, kasnije precrtan $\mathrm{u} »$ Varaždin razno«, pokazuje da je Horvat rukopis dijelio tematski. Predavao ga je u dijelovima, na što upućuje omotnica tintom ispisanim naslovom i crvenom olovkom naknadno unesenim ispravkom, »Povijest grada Varaždina. / Napisao dr. Rudolf Horvat. / Razni umetci Nastavak 3. dijela (od strane 190. do strane 254. ${ }^{132}$

127 HR-HDA-799. Horvat R., 3.4.17.1. Varaždin: bilješke, Prvi protokol (najveći).

128 HR-HDA-799. Horvat R., 3.4.17.5.3. Varaždin: prijepisi arhivske građe: sudnički zapisi Liber fassionum civitatis Varasdinensis, sjednički zapisi Prothocollum magistratuale liberae et regiae civitatis Varasdinensis pro annis 1592-1602. i politički zapisi Prothocollum politicum liberae et regiae civitatis Varasdinensis. HR-HDA-799. Horvat R., 3.4.17.4.1. Varaždin: ispisi iz periodike, Hrvatsko pravo, 1914-1916. grada Varaždina.

132 HR-HDA-799. Horvat R., 3.4.17.1. Varaždin: bilješke, omotnica Varaždin u 20. vijeku; omotnica Povijest grada Varaždina. 


\section{HORVATOVA PODJELA RUKOPISA}

Povjesnica Povijest grada Varaždina u nizu je tisuću iscrpnih Horvatovih tiskanih djela. Uključuju radove o historiografiji i povijesti Hrvatske, ${ }^{133}$ regija, ${ }^{134}$ lokalnih sredina i gradova. ${ }^{135}$ Sačuvani arhivski spisi pokazuju da je Horvat komentirao i kazalo rukopisa. Ideju o peterodjelnoj podjeli kakvu je iznio još 1909. godine proveo je u tiskanoj studiji Varaždin koncem 16. vijeka (1912.); čine je crtice o upravi, sudstvu, crkvi i privredi. ${ }^{136}$ Osvrćući se na rukopis u kolovoškom pismu 1934. godine zamislio je razrađeniju osmerodijelnu podijelu: opća politička i posebna povijest (crkve, školstva, gradskog poglavarstva, odnosno uprave, sudstva, privrede, »financijalnih « prilika i socijalnih prilika). ${ }^{137}$ Ideju o višedjelnoj i tematskoj podijeli proveo je u djelima Slavonija (1933.) i Podravina (1936.). ${ }^{138}$ Podjela rukopisa kakvu je zamislio u kolovoškom pismu skoro je istovjetna podjeli tiskane Prošlosti grada Zagreba (1942.), koja sadrži nekoliko dodatnih poglavlja: o zagrebačkoj kronici, gradska uprava, sudbenost, zagrebačke crkve i kapele, zagrebački samostani, crkve, škole i odgojni zavodi, znanstveni zavodi, iz zagrebačke umjetnosti, obrt u Zagrebu, promet, trgovina, socijalne prilike u starom Zagrebu. ${ }^{139}$

U Horvatovom fondu su i dva lista na kojima je Horvat tintom ispisao naslove crtica u mogućemu »sadržaju « rukopisa. List naslovljen Sadržaj broji padajući niz od 1 do 70, koji se do naslova 93 nastavlja na listu Nastavak sadržaja povijesti Varaždina, pri čemu crtice nije nizao kronološki. Na olovkom naslovljeni list Moja Kulturna povijest Varaždina Horvat je tintom ispisao »kazalo/sadržaj« s naslovima svih poglavlja u padajućem nizu, olovkom ispisanim rednim brojevima prema kojima se oni pojavljuju, slijede im olovkom ispisani broj listova koja poglavlja sadrže. U gornjemu lijevom kutu olovkom je zapisao podatak da rukopis broji 409 listova, a prema dnu opasku: »Predano gradskom poglavarstvu u Varaždinu

133 Rudolf HORVAT, Hrvatska na mučilištu, Školska knjiga, Zagreb, 1992. [1942.], dio, Izdanje Matice hrvatske i Tisak »Tipografije« d. d. Zagreb, Zagreb, 1941.

135 Rudolf HORVAT, Poviest slob. i kr. grada Koprivnice, Hrvatski tiskarski zavod d.d., Zagreb, 1943.; Isti, Poviest slob. $i$ kr. grada Koprivnice, MAG Agencija za marketing, dizajn i grafičke usluge, Koprivnica, 1988.

136 HORVAT, 1912.

137 DAVŽ, [0649] GPV - Varaždin (1918.-1941.), Zapisnici skupština Gradskog zastupstva, Gradskog vijeća 1919.-1941., Zapisnik za 1933. godinu, sjednica 6. listopada 1933., 45-52.

138 Rudolf HORVAT, Hrvatska Podravina. Povijesne rasprave, crtice i bilješke, Izdanje »Pramatice« Nakl. K. D. Petar Kvaternik i drugovi, Zagreb, 1933.; Isti, Slavonija: povijesne rasprave, crtice i bilješke: knjiga 1., Tisak »Tipografije« d.d., Zagreb, 1936.; Isti, Slavonija I i II, Slavonska naklada »Privlačića«, Vinkovci, 1994.

139 Rudolf HORVAT, Prošlost grada Zagreba, ur. Albert Goldstein, August Cesarec Izdavač d.o.o., Atlantic Paper d.o.o., Zagreb, 1992. [1942.]. 
na proljeće g.1939.«. ${ }^{140}$ Ta poglavlja nisu nizana prema rastućem broju, a premetanjem se dobiva ovakva podjela, to jest, kazalo: župna crkva sv. Nikole, samostanske crkve, varaždinske kapele, samostani, gradska uprava, sudbene prilike, financijske prilike, socijalne prilike, privredne prilike, varaždinska trgovina, obrt u Varaždinu, Zakmadrijevo sjemenište, stare hrv. oporuke u Var., akatolici u Var, razne bilješke (Prikaz 1, lijevo). Zamislio je višedjelnu podjelu koju je predvidio za II. dio rukopisa koju je obrazložio u kolovoškom pismu.

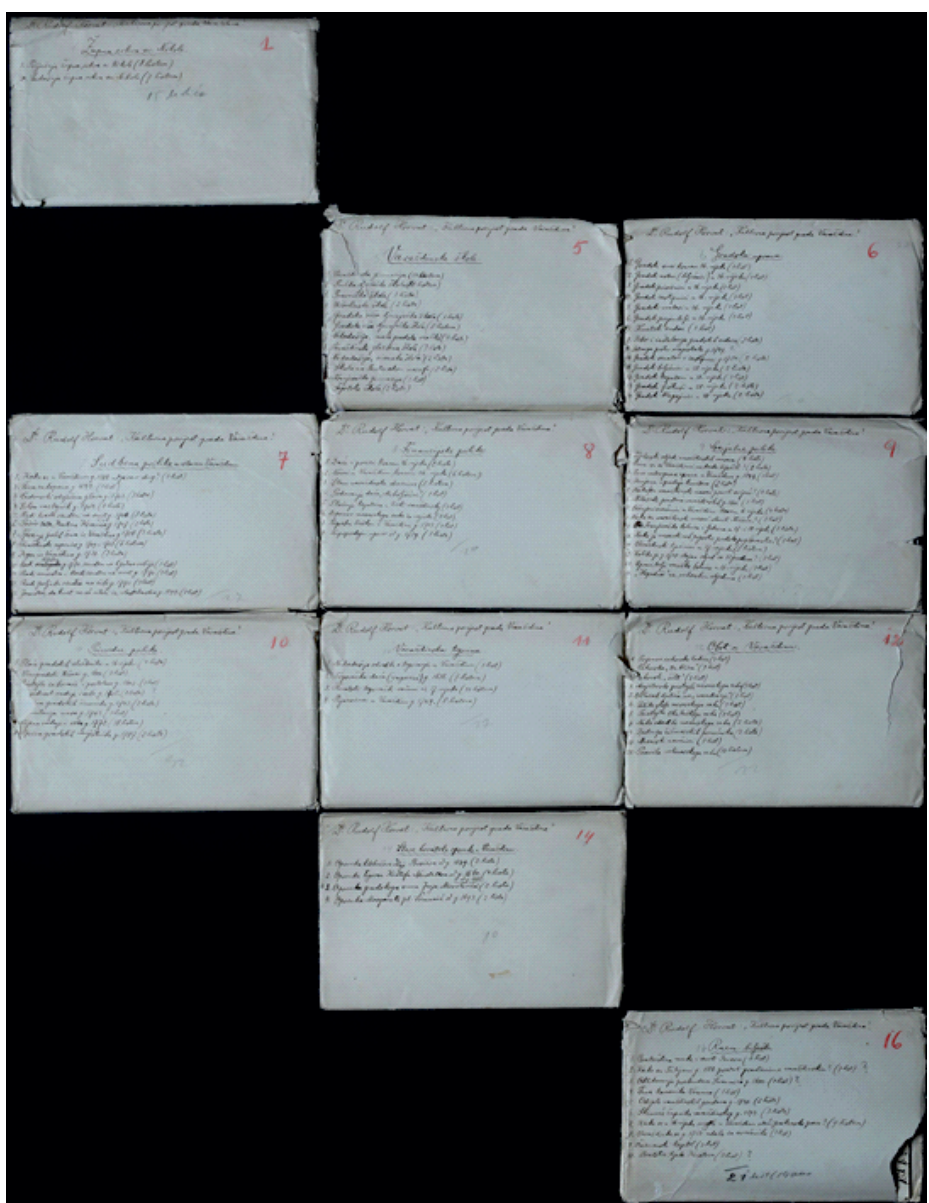

Slika 2. Rudolf Horvat, Kulturna povijest grada Varaždina, 1939., 277 listova $21 \times 17 \mathrm{~cm}$, u 16 omotnica 18x12 cm, rukopis (tinta i olovka) i strojopis na papiru, Gradski muzej Varaždin (foto: Andrej Švoger, GMV).

140 Za sve tri bilješke vidi: HR-HDA-799. Horvat R., 1. 2. Bilješke Rudolfa Horvata o vlastitim radovima, Sadržaj; Nastavak sadržaja o povijesti grada Varaždina; Moja Kulturna povijest Varaždina. 


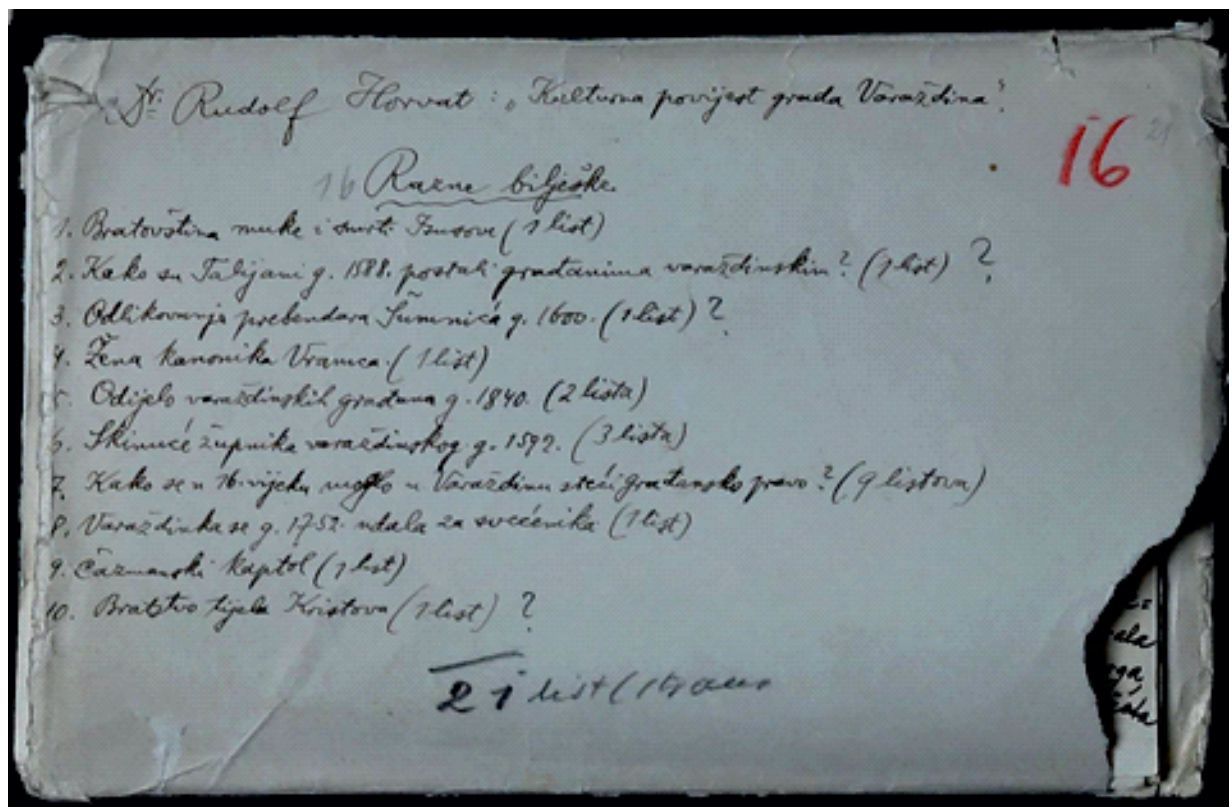

Slika 3. Rudolf Horvat, Kulturna povijest grada Varaždina, 1939., 277 listova $21 \times 17 \mathrm{~cm}$, u 16 omotnica $18 \times 12 \mathrm{~cm}$, rukopis (tinta i olovka) i strojopis na papiru, omotnica 1, Gradski muzej Varaždin (foto: Andrej Švoger, GMV).

\section{PRIKAZ 1.}

Prijepis bilješke R. Horvata Moja kulturna povijest Varaždina (Hrvatski državni arhiv)

Moja kulturna povijest Varaždina (409 lista / strana), kazalo

5 Varaždinske škole 54 strana 4 -||- samostani 37 strana 12 Obrt u Varaždinu 22 strane 1 Župna crkva sv. Nikole 15 strana

3 Varaždinske kapele 32 strana

2 Samostanske crkve 16

8 Financijske prilike 20
Prijepis naslova omotnica rukopisa $\mathrm{R}$. Horvata

(Gradski muzej Varaždin)

\section{Dr. Rudolf Horvat: Kulturna povijest grada Varaždina [277 lista, kazalo]}

1 Župna crkva sv. Nikole (15)

[2 Samostanske crkve, nedostaje]

[3 Varaždinske kapele, nedostaje]

[4 Varaždinski samostani, nedostaje]

5. Varaždinske škole (54)

6 Gradska uprava (20)

7 Sudbene prilike (27) 
6 Gradska uprava 20

9 Socijalne prilike 32

10 Privredne prilike 29

13 Zakmardijevo sjemenište 29

11 Varaždinska trgovina 27

16 Razne bilješke 21

14 Stare hrv. oporuke u Var. 10

7 Sudbene prilike 27

15 Akatolici u Var. 18
8 Financijske prilike (20)

9 Socijalne prilike (29)

10 Privredne prilike (32)

11 Varaždinska trgovina (27)

12 Obrt u Varaždinu (22)

[13 Zakmardijevo sjemenište, nedostaje]

14 Stare hrvatske oporuke u

Varaždinu (10)

[15 Akatolici u Varaždinu, nedostaje]

16 Razne bilješke (21)

\section{DIO RUKOPISA - OSTAO NEOBJAVLJEN}

Uspoređivana Horvatova tiskana djela zbir su kronološki sabranih povijesnih crtica. Istom idejom Horvat je pristupio rukopisu Povijest grada Varaždina, jer tiskanu knjigu čine crtice s kronološki poredanim povijesnim događajima u Varaždinu. U predgovoru knjige Miroslav Kurelac [1993.] navodi da je čine dva dijela, prvi obrađuje povijest grada Varaždina od doba narodnih vladara do 1848. godine, a drugi od 1848. do 1914. godine, ${ }^{141}$ pri čemu svaki sadrži podatke o upravnoj, gospodarskoj i kulturnoj prošlosti grada. Što se dogodilo s tematskim, kulturnim poglavljima koja je Horvat predvidio u kolovoškom i siječanjskom pismu?

Odgovor daje sačuvani Horvatov rukopis u Gradskom muzeju Varaždin, naslova Povijest grada Varaždina. Svezak I. Napisao profesor dr. Rudolf Horvat. Sastoji se od 706 rukopisnih i nekoliko strojopisnih listova papira čije su prednje stranice gusto ispisane i natipkane s nekoliko Horvatovih uređivačkih opaski i ispravaka. ${ }^{142}$ Svaku crticu iz povijesti grada Horvat je zabilježio na njezinom listu (katkada dva), na prvoj strani, a crvenom olovkom na vrhu zabilježio je redni broj stranice rukopisa. Listove, odnosno crtice, Horvat je sabrao kronološki i grupirao ih u dva dijela pri čemu drugi dio, naslovljen Novi Varaždin, obuhvaća događaje nakon 1848. godine (sl 1), što odgovara podjeli tiskane knjige koju je opisao Kurelac. Dio naslova rukopisa - Svezak I - upućuje na zaključak da je Horvat predvidio i nastavak, svezak / sveske.

141 KURELAC, 1993., IX-XI.

142 Rudolf HORVAT, Povijest grada Varaždina. Svezak I. Napisao profesor dr. Rudolf Horvat, 1939., rukopis (tinta) i strojopis na papiru, 21x17 cm, 706 listova, Gradski muzej Varaždin (dalje: GMV), inv. br. GMV KPO 12758. 
Gradski muzej Varaždin čuva još jedan Horvatov rukopis (sl 2). ${ }^{143}$ Njega čini jedanaest omotnica. Svaku je tintom naslovio Dr. Rudolf Horvat »Kulturna povijest grada Varaždina ", po njezinoj sredini ispisao naslov teme, ispod teme kronološki poredao naslove crtica i u zagradi zapisao broj listova koji sadrži. Nasred ili u kutu omotnice ispisao je broj listova koji se nalaze $u$ omotnicama, a u desnom gornjem kutu crvenom je olovkom naznačio redni broj omotnice. Listove je ispisivao tintom ili rjeđe strojem, a naknadno ih je ispravljao tintom, poput rukopisa prvog sveska. Ovom rukopisu Horvat je predvidio 16 omotnica, tj., 16 tematskih poglavlja. Nedostaje pet omotnica, a sačuvanih 11 omotnica koje broje 277 listova zajedno daju sadržaj: 1. Župna crkva sv. Nikole (15), 5. Varaždinske škole (54), 6. Gradska uprava (20), 7. Sudbene prilike (27), 8. Financijske prilike (20), 9. Socijalne prilike (29), 10. Privredne prilike (32), 11. Varaždinska trgovina (27), 12. Obrt u Varaždinu (22), 14. Stare hrvatske oporuke u Varaždinu (10), 16. Razne bilješke (21).

Nedostaju omotnice numerirane brojem 2, 3, 4, 13 i 15. Podjela rukopisa Kulturne povijesti grada Varaždina odgovara podjeli rukopisa koji je Horvat ispisao na listu Moja kulturna povijest Varaždina (vidi Prikaz 1, lijevo). Uz razlike u 9. i 10. poglavlju odgovara i broj listova koji čine ta dva poglavlja (vidi Prikaz 1, desno). Autorica ovog članka smatra da se kazalo na zagrebačkom listu odnosi na rukopis u omotnicama, koji je, sudeći prema listu, Horvat predao u proljeće 1939. godine. Uzmu li se u obzir i Horvatovi komentari, autorica smatra da je drugi sačuvani rukopis zapravo II. dio povjesnice koji je zamislio u kolovoškom pismu 1933. godine, a što je Horvat i potvrdio siječanjskim pismom u kojem navodi (ne) dovršena poglavlja tog dijela, a koja naslovom odgovaraju naslovima omotnica. To jest, u svakoj sačuvanoj omotnici Horvat je spremio pojedino poglavlje tog drugog dijela naručenog rukopisa, koji bi mogao nasloviti Svezak II. Naposljet$\mathrm{ku}$, zaključuje se da ta dva sačuvana muzejska »rukopisa« čine jedinstveni rukopis Povijest grada Varaždina, koji je Horvat predao u dijelovima u pet različitih navrata: u svibnju 1934., 1935., kolovozu 1936., 1938. i proljeće 1939. godine tijekom osobnog dolaska u Varaždin ili posredstvom gradonačelnika Novakovića ili dragog mu prijatelja. Zaključuje se da je rukopisni I. dio (opća, politička povijest) tiskan 1993. godine, dok je II. dio s tematskim poglavljima, sačuvan u omotnicama, ostao neobjavljen.

\section{OD PREDAJE DO POHRANE - GDJE SE RUKOPIS NALAZIO?}

Rukopis u dijelovima do naručitelja "putuje « izravno od autora ili posredstvom gradonačelnika ili Horvatovog dragog prijatelja. O rukopisu se čita u vezi

143 Rudolf HORVAT, Kulturna povijest grada Varaždina, 1939., 277 listova 21x17 cm, u 16 omotnica $18 \times 12 \mathrm{~cm}$, rukopis (tinta i olovka) i strojopis na papiru, GMV, inv. br. GMV 67791. 
niza događaja 1941. godine. Uspostavom NDH i »po dolasku njemačke vojske u Varaždin«, piše Vladimir Huzjan [2012.], »11. travnja smijenjena je dotadašnja gradska uprava i postavljena nova«, novoimenovan povjerenik općine Ljudevit Ban ubrzo je dao otkaz, pa ga je zamijenio ga je Slavko Medvedović. Pri svečanoj primopredaji dužnosti u gradskoj vijećnici 30. travnja predani su službeni spisi i predmeti grada Varaždina s raznorodnim kulturnopovijesnim predmetima, a među njima i rukopisom. ${ }^{144}$ Zapisnik primopredaje u točki V. donosi podatke o mjestu i načinu njihove pohrane i popis od 30 predmeta grupiranih u 18 podtočaka. Izdvaja se: »V. Predan je ključ od željezne blagajne/ sistem Wiese et Comp. Wien/ u uredovnici gradskog načelnika, dočim ključ tikač imade kao suključar ravnatelj pomoćnih ureda. U ovoj blagajni su pohranjene i predane slijedeće stvari: [...] 3/ Prepis originalne povelje Kralja Andrije iz godine 1209 [...] 5/ Srebreni pečat grada Varaždina u posebnoj okrugloj drvenoj kutiji. [...] 12/ Jedan primjerak Ebnerove povijesti grada Varaždina. 13/ Šst svezaka rukopisa povijesti grada Varaždina od Dr. Rudolfa Horvata/ I dio i II dio/ i 16 svezaka u kuvertama/ iste povijesti II dio /kulturna povijest grada Varaždina/ sve originalni rukopis «. ${ }^{145}$ Predmeti su se čuvali u uredu gradskog načelnika u željeznoj blagajni koju je, na Englehardtov poticaj, u listopadu 1941. godine, zamijenila željezna blagajna $(200 \times 103 \times 68 \mathrm{~cm})$ sistema »Wertheim-Wien«, koju je odvjetnik gradskoj vlasti prodao za predloženih 12.500 Kuna. ${ }^{146}$ Gdje je blagajna završila? Je li se rukopis u njoj čuvao do pohrane u muzeju ili je imao usputnu stanicu?

Nepunih četiri desetljeća poslije, Jasna Tomičić [1981.] je otvorila pitanje kada je rukopis »zalutao u ladice muzeja«, a namjerom da se on objavi 1981. godine u povodu obilježavanja osam stoljeća od prvog spomena grada Varaždina odgovorila da se rukopis već tada čuvao u muzeju. Jer, takvim ga opisuju brojni istraživači u prilozima u zborniku skupa. ${ }^{147}$ Niti tjedan dana poslije skupa, muzeju su, prema njegovoj knjizi ulaska, 9. listopada predani, između ostalih, rukopis Ebnera i »pečatnjak grada Varaždina od srebra, kružna oblika s udubljenim reljefom lika gradskog tornja«, ali nema zapisa za Horvatov rukopis. ${ }^{148}$ Njega je, prema riječima umirovljenog muzejskog savjetnika Miroslava Klemma, u muzeju zatekla Jasna Tomičić (kustos od 1965.). Rukopis je u muzej stigao između 1941. i

144 HUZJAN, 2012., 370. nica 31. listopada 1941., 130, točka 246.

147 Varaždinski zbornik: zbornik radova sa znanstvenog skupa održanog u Varaždinu od 1. do 3. listopada 1981., JAZU, Skupština općine Varaždin, ur. Andre Mohorovičić, Zagreb - Varaždin, 1983., prilozi M. Ilijanić i S. Kapustića, I. Lentić-Kugli, Z. Herkova, Đ. Antauera, V. Pletenca.

148 Unos br. 3727 (Ebner) i br. 3470 (pečatnjak), Knjiga ulaska (od 1965. do 2004.), GMV. 
1965., moguće nakon 1945. godine, nakon što je etiketa »osuđeni povjesničar« na zaborav osudila i Horvatov rukopis.

\section{ZAKLJUČAK}

Na temelju podacima obilne arhivske građe u varaždinskom i zagrebačkom arhivu, upotpunjuje se slika o ugovaranju i o tijeku pisanja povjesnice Povijest grada Varaždina povjesničara Rudolfa Horvata. Iz sačuvanih točaka sjednica i dopisa gradske vlasti, korespondencije između gradske vlasti i Horvata iščitava se napor autora u provođenju opsežnog istraživanja povijesti grada Varaždina i obradi građe za sastavljanje rukopisa, njegovoj viziji o rukopisu i ustrajnosti u isplati honorara koji je neprestano smatrao primjerenim za svoj skoro tridesetogodišnji rad. Iščitava se i napor naručitelja da visinu honorara provjeri sa znanstvenim i nakladničkim institucijama onog doba te je ugovori u skladu s tada lošijim gospodarskim uvjetima. Naručitelj se o troškovima tiskanja povjesnice raspitivao kod različitih tiskara poslavši im za predložak tiskane historiografske radove, pa i Horvatove. U njezin nastanak uključivao je i mjerodavne osobe - zastupnike i ne-zastupnike grada Varaždina, koji će na temelju svog stručnog iskustva i rada, putem triju višečlanih odbora donositi stručne zaključke o rukopisu. Horvat je na rukopisu Povijest grada Varaždina radio punih trideset godina. Zaključuje da je taj rukopis predao u dijelovima u pet navrata, u ožujku 1934., 1935., 1936., kolovozu 1938. i proljeće 1939. godine, izravno osobnim dolaskom u Varaždin ili posredstvom gradonačelnika Novakovića ili dragog mu prijatelja. Horvat je zamislio višedijelni sadržaj rukopisa: njegov I. dio, opća ili politička povijest tiskana je 1993. godine, a tematski II. dio sa zasebnim poglavljima ostao je neobjavljen: pod naslovom Dr. Rudolf Horvat: Kulturna povijest grada Varaždina, skupa s objavljenim prvim djelom, čuva se u Gradskom muzeju Varaždin. Želeći omogućiti Horvatu vrijeme za istraživanje i pisanje povjesnice, gradska vlast je uz pomoć tadašnjeg hrvatskog bana Pavla Raucha, piscu ishodila premještaj u Zemaljski kraljevski arhiv u Zagrebu, gdje je istraživao arhivsku građu, a novčanom isplatom pripomogla mu arhivska istraživanja u austrijskim i mađarskom arhivu i tisak kratke studije Varaždin koncem 16. vijeka. U zagrebačkom arhivu Horvat je imao mogućnosti i vremena istraživati građu ne samo o povijesti Varaždina, nego i o povijesti drugih hrvatskih gradova, na temelju koje je mogao raditi i na povjesnicama tih gradova. U tom se pogledu ističe i skroman doprinos varaždinskih gradskih zastupnika davne 1909. godine za hrvatsku historiografiju. U svezi s tim, s obzirom na to da je Horvat na rukopisu radio nepunih trideset godina i da ga je u dijelovima predao do 1939. godine, rukopis bi se trebao promatrati u kontekstu historiografskih radova nastalih tijekom 1930-ih godina. Naposljetku, ovim se radom 
iznio tijek nastanka rukopisa, dok se njegov sadržaj (u tiskanoj knjizi 1993., ali i u neobjavljenom dijelu rukopisa) može smatrati zanimljivom temom za buduća istraživanja.

\section{BIBLIOGRAFIJA}

\section{ARHIVSKI IZVORI:}

\section{Državni arhiv u Varaždinu:}

1. Državni arhiv u Varaždinu, [0016] Gradsko poglavarstvo Varaždin - Varaždin (1850.-1918.), Kazala k urudžbenim zapisnicima »političkih spisa« 1851.1918., 1909. godina, s. $p$.

2. Državni arhiv u Varaždinu, [0016] Gradsko poglavarstvo Varaždin - Varaždin (1850.-1918.), Opći ili »politički spisi« 1850.-1918., 6570/1909.

3. Državni arhiv u Varaždinu, [0016] Gradsko poglavarstvo Varaždin - Varaždin (1850.-1918.), Zapisnici sjednica poglavarstva, zastupstva i pojedinih odbora 1852.-1918.: Zapisnik za 1909. godinu, sjednica 28. travnja 1909., s. p.

4. Državni arhiv u Varaždinu, [0025] Gradsko poglavarstvo Varaždin - Varaždin (1941.-1945.), Zapisnici sjednica Gradskog zastupstva 1941., sjednica 31. listopada 1941., 130, točka 246.

5. Državni arhiv u Varaždinu, [0025] Gradsko poglavarstvo Varaždin - Varaždin (1941.-1945.), Opći spisi 1941.-1945., 7207/1941.

6. Državni arhiv u Varaždinu, [0649] Gradsko poglavarstvo Varaždin - Varaždin (1918.-1941.), Kazala općih spisa 1918.-1941., Kazalo za 1933. godinu, s. p. / Kazalo za 1934. godinu, s. p.

7. Državni arhiv u Varaždinu, [0649] Gradsko poglavarstvo Varaždin - Varaždin (1918.-1941.), Opći spisi 1918.-1940.: 8515/1926, 585/1927, 6447/1940.

8. Državni arhiv u Varaždinu, [0649] Gradsko poglavarstvo Varaždin - Varaždin (1918.-1941.), Zapisnici skupština Gradskog zastupstva, Gradskog vijeća 1919.-1941.:

- Zapisnik za 1933. godinu, sjednica 6. listopada 1933., 45-52.

- Zapisnik za 1934. godinu, sjednica 19. siječnja 1934., 34-35.; sjednica 25. svibnja 1934., 51.

- Zapisnik za 1936. godinu, sjednica 30. ožujka 1936., prilog: prijedlog proračuna za 1936/37. god., 15.

- Zapisnik za 1937. godinu, sjednica 30. ožujka 1937., prilog: prijedlog proračuna za 1937/38. god., s. $p$.

- Zapisnik za 1940. godinu, sjednica 2. prosinca 1940., 77-78 (192-193). 
9. Državni arhiv u Varaždinu, [0649] Gradsko poglavarstvo Varaždin - Varaždin (1918.-1941.), Korespondencija Gradskog poglavarstva Varaždin i Rudolfa Horvata o knjizi »Povijest grada Varaždina« 1933.-1939., sadrži spise: 13097/1933, 14508/1933, 17803/1933, 20243/1933, 20593/1933, 21717/1933, 36/1934, 106/1934, 167/1934, 2096/1934, 4413/1934, 6270/1934, 10760/1934, 17534/1935, 13919/1936, 12463/1937.

- neurudžbiran dopis Štamparije »Gaj«, 1. ožujka 1934.

- pismo Rudolfa Horvata 24. kolovoza 1933., urudžbiran kao spis 13935/1933.

- neurudžbirano pismo Rudolfa Horvata 10. siječnja 1934., uz spis 167/1934.

- neurudžbirano pismo Rudolfa Horvata 29. ožujka 1934.

- neurudžbirano pismo Rudolfa Horvata 21. prosinca 1938.

- historijate varaždinskih društava.

\section{Hrvatski državni arhiv u Zagrebu:}

\section{Fond: Hrvatski državni arhiv:}

1. HR-HDA-511. Hrvatski državni arhiv, Spisi 1791-1945, Dopis Gradskog poglavarstva u Varaždinu Kraljevskom državnom arhivu u Zagrebu: 7. listopada 1926., 17. siječnja 1927.

2. HR-HDA-511. Hrvatski državni arhiv, Spisi 1791-1945, Dopis Kraljevskog državnog arhiva u Zagrebu Gradskom poglavarstvu u Varaždinu: 3. kolovoza 1923., 30. rujna 1926., 15. siječnja 1927.

3. HR-HDA-511. Hrvatski državni arhiv, Spisi 1791-1945, Dopis Kraljevskog hrvatsko-slavonsko-dalmatinskog zemaljskog arhiva u Zagrebu Poglavarstvu grada Varaždina: 18. kolovoza 1917., 7. siječnja 1918.

4. HR-HDA-511. Hrvatski državni arhiv, Spisi 1791-1945, Dopis Kraljevskom hrvatsko-slavonsko-dalmatinskom zemaljskom arhivu u Zagrebu 12. listopada 1910.

5. HR-HDA-511. Hrvatski državni arhiv, Spisi 1791-1945, Dopis Poglavarstva grada Varaždina Kraljevskom državnom arhivu u Zagrebu 23. lipnja 1923.

6. HR-HDA-511. Hrvatski državni arhiv, Spisi 1791-1945, Dopis Poglavarstva grada Varaždina Kraljevskom hrvatsko-slavonsko-dalmatinskom zemaljskom arhivu u Zagrebu: 25. studenog 1910., 5. prosinca 1910., 25. svibnja 1916., 10. siječnja 1917., 11. siječnja 1917., 3. veljače 1917., 31. siječnja 1918.

7. HR-HDA-511. Hrvatski državni arhiv, Urudžbene knjige. [Zapis za spis: 171/1910, 172/1910, 199/1910, 212/1910, 213/1910, 109/1916, 16/1917, 17/1917, 18/1917, 28/1917, 30/1917, 314/1917, 7/1918, 44/1918, 101/1923, 130/1923, 187/1926, 203/1926, 15/1927, 31/1927] 


\section{Fond: Osobni fond Rudolf Horvat:}

1. HR-HDA-799. Horvat R., 1.1. Bilješke R. Horvata o vlastitim predavanjima, Javno sam govorio na trgovima 1925.

2. HR-HDA-799. Horvat R., 1. 2. Bilješke R. Horvata o vlastitim radovima, Moja Kulturna povijest Varaždina; Moje radnje iz povijesti grada Varaždina; Nastavak sadržaja o povijesti grada Varaždina; Sadržaj.

3. HR-HDA-799. Horvat R., 3.4.17.1. Varaždin: bilješke, Grb Varaždina.

4. HR-HDA-799. Horvat R., 3.4.17.1. Varaždin: bilješke, omotnica Povijest grada Varaždina; omotnica Varaždin u 20. vijeku.

5. HR-HDA-799. Horvat R., 3.4.17.1. Varaždin: bilješke, Proi protokol (najveći).

6. HR-HDA-799. Horvat R., 3.4.17.4.1. Varaždin: ispisi iz periodike, Hrvatsko pravo, 1914-1916.

7. HR-HDA-799. Horvat R., 3.4.17.5.3. Varaždin: prijepisi arhivske građe: sudnički zapisi Liber fassionum civitatis Varasdinensis, sjednički zapisi Prothocollum magistratuale liberae et regiae civitatis Varasdinensis pro annis 1592-1602. i politički zapisi Prothocollum politicum liberae et regiae civitatis Varasdinensis.

\section{MUZEJSKA GRAĐA I DOKUMENTACIJA:}

1. Knjiga ulaska (1965.-2004.), Gradski muzej Varaždin.

2. Rudolf HORVAT, Povijest grada Varaždina. Svezak I. Napisao profesor dr. Rudolf Horvat, 1939., rukopis (tinta) i strojopis na papiru, 21x17 cm, 706 listova, Gradski muzej Varaždin, inv. br. GMV KPO 12758.

3. Rudolf HORVAT, Kulturna povijest grada Varaždina, 1939., 277 listova $21 \times 17 \mathrm{~cm}$, u 16 omotnica 18x12 cm, rukopis (tinta i olovka) i strojopis na papiru, Gradski muzej Varaždin, inv. br. GMV 67791.

\section{TISKANI RADOVI:}

1. »Horvat, Rudolf«, Hrvatski biografski leksikon, ur. Trpimir Macan, Zagreb, 2002., 657-658.

2. Zvonimir DESPOT, »Politički put dr. Rudolfa Horvata «, Dr. Rudolf Horvat - život i djelo: u povodu 50. obljetnice smrti (1947.-1997.) i 125. obljetnice rođenja (1873-1998.): zbornik referata podnijetih na Znanstvenom skupu Dr. Rudolf Horvat - život i djelo, održanog u Koprivnici 1997. godine, Hrvatsko povijesno društvo, Družba »Braća Hrvatskog Zmaja«, Nakladna kuća Dr. Feletar, ur. Dragutin Feletar, Koprivnica, 1998., 59-71. 
3. Dražen ERNEČIĆ, »Dr. Rudolf Horvat i Koprivnica«, Rudolf HORVAT, Poviest slob. i kr. grada Koprivnice, Ogranak Matice hrvatske, Koprivnica, 2003. [1943.], 299-319.

4. Dražen ERNEČIĆ, »Uvodno slovo«, Podravski zbornik, Muzej grada Koprivnice, ur. Hrvoje Petrić, Koprivnica, br. 23, 1997., 9-10.

5. Rudolf HORVAT, Hrvatska na mučilištu, Školska knjiga, Zagreb, 1992. [1942.].

6. Rudolf HORVAT, Hrvatska Podravina. Povijesne rasprave, crtice i bilješke, Izdanje »Pramatice« Nakl. K. D. Petar Kvaternik i drugovi, Zagreb, 1933.

7. Rudolf HORVAT, Lika i Krbava: povijesne slike, crtice i bilješke: Svezak I. Opći dio / Svezak II. Posebni dio, Izdanje Matice hrvatske i Tisak»Tipografije« d. d. Zagreb, Zagreb, 1941.

8. Rudolf HORVAT, Poviest slob. i kr. grada Koprivnice, Hrvatski tiskarski zavod d.d., Zagreb, 1943.

9. Rudolf HORVAT, Poviest slob. i kr. grada Koprivnice, MAG Agencija za marketing, dizajn i grafičke usluge, Koprivnica, 1988.

10. Rudolf HORVAT, Povijest grada Varaždina, ur. Andre Mohorovičić, HAZU Zavod za znanstveni rad Varaždin i Grad Varaždin, Varaždin, 1993.

11. Rudolf HORVAT, Povjest Medjumurja, Knjižara St. Kugli, Zagreb, 1907.

12. Rudolf HORVAT, Prošlost grada Zagreba, ur. Albert Goldstein, August Cesarec Izdavač d.o.o., Atlantic Paper d.o.o., Zagreb, 1992. [1942.]

13. Rudolf HORVAT, Slavonija: povijesne rasprave, crtice i bilješke: knjiga 1., Tisak »Tipografije« d.d., Zagreb, 1936.

14. Rudolf HORVAT, Slavonija I i II, Slavonska naklada »Privlačića«, Vinkovci, 1994.

15. Rudolf HORVAT, Varaždin koncem 16. vijeka, Tisak Kraljevske zemaljske tiskare, Zagreb, 1912.

16. Mirko HIKEC, »Predgovor«, Poviestni spomenici slobodnog i kraljevskog grada Varaždina. Svezak prvi. Zbornik izprava 1209.-1526. iz arhiva Grada Varaždina., Svobodina »Narodna tiskara«, Obćina slob. i kr. grada Varaždina, Varaždin, 1942., VI-VIII.

17. Vladimir HUZJAN, Varaždin i vojska u međuratnom razdoblju (1918.-1941.), Zavod za znanstveni rad Varaždin HAZU, Varaždin, 2017.

18. Vladimir HUZJAN, »Varaždin u zadnjim mjesecima Kraljevine Jugoslavije i prvim mjesecima Nezavisne Države Hrvatske«, Radovi zavoda za znanstveni rad HAZU Varaždin, HAZU, gl. ur. Stjepan Damjanović, Zagreb - Varaždin, br. 23, 2012., 363-399. 
19. Vladimir HUZJAN i Ivan OBADIĆ, »Historiografija varaždinskog kraja u 20. stoljeću«, Historia varasdiensis: časopis za varaždinsku povjesnicu, Društvo povjesničara grada Varaždina i Varaždinske županije, gl. ur. Hrvoje Petrić i Ivan Obadić, Varaždin, br. 2, 2012., 61-90.

20. Mira KOLAR-DIMITRIJEVIĆ, »Bib[1]iografija radova dra Rudolfa Horvata 1894-1945«, Dr. Rudolf Horvat - život $i$ djelo: u povodu 50. obljetnice smrti (1947.-1997.) i 125. obljetnice rođenja (1873-1998.): zbornik referata podnijetih na Znanstvenom skupu Dr. Rudolf Horvat - život $i$ djelo, održanog $u$ Koprionici 1997. godine, Hrvatsko povijesno društvo, Družba »Braća Hrvatskog Zmaja«, Nakladna kuća Dr. Feletar, ur. Dragutin Feletar, Koprivnica, 1998., 116-152.

21. Mira KOLAR-DIMITRIJEVIĆ, »Bibliografija radova dra Rudolfa Horvata 1894-1945«, Rudolf HORVAT, Poviest slob. i kr. grada Koprivnice, MAG Agencija za marketing, dizajn i grafičke usluge, Koprivnica, 1988., IXXVIII.

22. Mira KOLAR-DIMITRIJEVIĆ, »Dr. Rudolf Horvat i Hrvatska«, Rudolf HORVAT, Poviest slob. i kr. grada Koprivnice, Ogranak Matice hrvatske, Koprivnica, 2003. [1943.], 291-298.

23. Mira KOLAR-DIMITRIJEVIĆ, »Političko-kulturna djelatnost Rudolfa Horvata u Slavoniji«, Rudolf HORVAT, Slavonija I i II, Slavonska naklada »Privlačića«, Vinkovci, 1994., 273-294.

24. Mira KOLAR-DIMITRIJEVIĆ, »Povjesničar Rudolf Horvat i Koprivnička Podravina«, Podravski zbornik, Muzej grada Koprivnice, ur. Franjo Horvatić, Koprivnica, br. 19-20, 1993.-1994., 29-42.

25. Mira KOLAR-DIMITRIJEVIĆ, »Život hrvatskog povjesničara i političara Rudolfa Horvata «, Dr. Rudolf Horvat - život i djelo: u povodu 50. obljetnice smrti (1947.-1997.) i 125. obljetnice rođenja (1873-1998.): zbornik referata podnijetih na Znanstvenom skupu Dr. Rudolf Horvat - život i djelo, održanog u Koprivnici 1997. godine, Hrvatsko povijesno društvo, Družba »Braća Hrvatskog Zmaja«, Nakladna kuća Dr. Feletar, ur. Dragutin Feletar, Koprivnica, 1998., 8-21.

26. Juraj KOLARIĆ, »Rudolf Horvat kao crkveni povjesničar«, Dr. Rudolf Horvat - život $i$ djelo: u povodu 50. obljetnice smrti (1947.-1997.) i 125. obljetnice rođenja (1873-1998.): zbornik referata podnijetih na Znanstvenom skupu Dr. Rudolf Horvat - život i djelo, održanog u Koprivnici 1997. godine, Hrvatsko povijesno društvo, Družba »Braća Hrvatskog Zmaja«, Nakladna kuća Dr. Feletar, ur. Dragutin Feletar, Koprivnica, 1998., 30-38. 
27. Miroslav KURELAC, »Predgovor «, Rudolf HORVAT, Povijest grada Varaždina, ur. Andre Mohorovičić, Zavod za znanstveni rad HAZU Varaždin i Grad Varaždin, Varaždin, 1993., IX-XI.

28. Hrvoje MATKOVIĆ, »Predgovor«, Rudolf HORVAT, Hrvatska na mučilištu, Školska knjiga, Zagreb, 1992. [1942.], VIII-IX.

29. Hrvoje PETRIĆ i Sonja POLJAK, »O historiografiji Varaždina u ranom novom vijeku (16.-18. stoljeće)«, Historia varasdiensis: časopis za varaždinsku povjesnicu, Društvo povjesničara grada Varaždina i Varaždinske županije, gl. ur. Hrvoje Petrić i Ivan Obadić, Varaždin, br. 2, 2012., 11-23.

30. Spomenka TEŽAK, »Pregled historiografije o gradu Varaždinu u 19. stoljeću«, Historia varasdiensis: časopis za varaždinsku povjesnicu, Društvo povjesničara grada Varaždina i Varaždinske županije, gl. ur. Hrvoje Petrić i Ivan Obadić, Varaždin, br. 2, 2012., 25-59.

31. Varaždinski zbornik: zbornik radova sa znanstvenog skupa održanog u Varaždinu od 1. do 3. listopada 1981., JAZU, Skupština općine Varaždin, ur. Andre Mohorovičić, Zagreb - Varaždin, 1983.

\section{NOVINE:}

1. Rudolf HORVAT, »O milosrdju varaždinskih gradjana u godini 1601.«, Narodno jedinstvo, 7. veljače 1929., br. 6, 3.

2. Rudolf HORVAT, »Postanak grada Varaždina«, Hrvatske pravice, 9. srpnja 1910., br. 28, 1-2.;

3. Rudolf HORVAT, »Postanak grada Varaždina«, Hrvatsko pravo, 23. rujna 1916., br. 39, 2-3.

4. Rudolf HORVAT, »Što je s povješću grada Varaždina?«, Slobodni gradjanin, 29. studenog 1919., br. 36, 4.

5. A. KLARIĆ, »'Povijest grada Varaždina' «, Varaždinske vijesti, 31. ožujka 1993., br. 2515 (12), 7.

6. Stjepan KROPEK, »Kad ćemo dobiti povijest grada Varaždina?«, Varaždinske novosti, 14. travnja 1933., br. 175, 9.

7. D. PERIČIĆ, »Skup o Rudolfu Horvatu«, Varaždinske vijesti, 26. studenog 1997., br. 2759, 12

8. Denis PERIČIĆ, »Zanijekani povjesničar«, Varaždinske vijesti, 17. ožujka 1993., br. 2513, 9.

9. PUKLER, »Kakova da bude povijest Varaždina?«, Hrvatske pravice, 12. ožujka 1910., br. 11, 2.

10. s. a., »700 godišnjica slobodnog i kr. grada Varaždina.«, Naše pravice, 16. prosinca 1909 ., br. 50, 3 . 
11. s. a., »I. varaždinski dobrovoljni djevojački pjevački i tamburaški sbor u Varaždinu.«, Naše pravice, 2. lipnja 1910., br. 23, 5.

12. s. a., »Dojam dogadjanja u Varaždinu. Manifestacije u kazalištu«, Volja naroda, bez br., 22. listopada 1918., 2.

13. s. a., »Društvena zabava katoličkog djetićkog društva«, Naše pravice, 18. studenog 1909., br. 46, 3-4.

14. s. a., »Gajeva stogodišnjica i Varaždin.«, Naše pravice, 19. kolovoza 1909., br. 33, 5 .

15. s. a., »Gradsko kazalište«, Naše pravice, 6. svibnja 1909., br. 18, 5.

16. s. a., »Interesantno predavanje o Tomi Bakač-Erdödy-u«, Hrvatsko jedinstvo, 8. ožujka 1924., br. 4, 3.

17. s. a., »Interesantno predavanje«, Hrvatsko jedinstvo, 15. ožujka 1924., br. 5, s2.

18. s. a., »Iz skupštine gradskog zastupstva.«, Hrvatske pravice, 17. srpnja 1909., br. 29, 3.

19. s. a., "Jubilej grada Varaždina i obrtništvo.«, Hrvatske pravice, 12. lipnja 1909., br. 24, 3.

20. s. a., »K proslavi sedamsto-godišnjice grada Varaždina.«, Naše pravice, 29. srpnja 1909., br. 30, 5.

21. s. a., »K sedamstogodišnjici grada Varaždina I./II.«, Naše pravice, 29. srpnja 1909., br. 30, 3-4.; 5. kolovoza 1909., br. 31, 3-4.

22. s. a., »Katoličko djetićko društvo u Varaždinu«, Hrvatske pravice, 13. studenog 1909., br. 46, 7.

23. s. a., »Novo gradsko zastupstvo«, Varaždinske novosti, 2. srpnja 1931., br. $82,1$.

24. s. a., »Odgodjena proslava 700-godišnjice.«, Hrvatske pravice, 18. rujna 1909., br. 38, 5 .

25. s. a. »Oglas«, Varaždinske novosti, 20. ožujka 1941., br. 590, 5.

26. s. a., »Valjan predlog u zgodno vrieme.«, Hrvatske pravice, 19. lipnja 1909., br. $25,2$.

27. s. a., »Povijest grada Varaždina.«, Hrvatske pravice, 1. svibnja 1909., br. 18, 5-6.

28. s. a., »Povijest grada Varaždina.«, Naše pravice, 29. travnja 1909., br. 17, $4-5$.

29. s. a., »Proslava 700-godišnjice grada Varaždina.«, Naše pravice, 22. srpnja 1909., br. $29,3$.

30. s. a., »Proslava 700-godišnjice grada Varaždina odgodjena.«, Naše pravice, 9. rujna $1909 .$, br. 36,5 . 
31. s. a., »Proslava 700-godisnjice Varaždina u župnoj crkvi sv. Nikole«, Hrvatske pravice, 4 . prosinca 1909., br. 49, 7.

32. s. a., »* Proslava 700 godisnjice u crkvi sv. Nikole«, Hrvatske pravice, 11. prosinca 1909., br. 50, 4 .

33. s. a., »Proslava 700-godišnjice grada Varaždina.«, Hrvatske pravice, 27. studenog 1909., br. 48, 5 .

34. s. a., »Proslava 1000-godišnjice hrvatske državnosti.«, Narodno jedinstvo, 23. srpnja 1925., br. 10, 2.

35. s. a., »Pučka prosvjeta. Pučko predavanje u Varaždinu«, Volja naroda, 17. listopada 1918., br. 16, 4.

36. s. a., »Pučko predavanje u Varaždinu«, Volja naroda, 17. listopada 1918., br. 16,4 .

37. s. a., »Raspored proslave 1000-godišnjice u Varaždinu dne 11. i 12. srpnja 1925. «, Narodno jedinstvo, 9. srpnja 1925., br. 8, 2.

38. s. a., »Sa naše gradske vijećnice. «, Naše pravice, 1. rujna 1910., br. 36, 3-4.

39. s. a., »Sedamstogodisnjica grada Varaždina. «, Hrvatske pravice, 28. kolovoza 1909., br. 35, 5 .

40. s. a., »Sedamstogodišnjica grada Varaždina«, Varaždinski viestnik, 24. kolovoza 1901., br. 34, 2.

41. s. a., "Sedamsto - godišnjica grada Varaždina.«, Naše pravice, 2. rujna 1909., br. 35, 6 .

42. s. a., "Sjednica plenuma gradskog zastupstva«, Hrvatsko jedinstvo, 7. prosinca 1940., br. 165, 3.

43. s. a., "Što je sa poviješću grada Varaždina?«, Slobodni gradjanin, 1. studenog 1919., br. 32, 4.

44. s. a., »Telefonski adresar za grad Varaždin«, Varaždinske novosti, 11. siječnja 1940., br. 528, 5 .

45. s. a., »Važni dokumenti za gradju poviesti podravskih gradova.«, Naše pravice, 18. kolovoza 1910., br. 34, 5 .

46. s. a., »Važni dokumenti za gradju povijesti podravskih gradova.«, Hrvatske pravice, god. IV, br. 33, 13. kolovoza 1910., 5.

47. T. ŠUMIGA, »Grad Kulture, i otvorena srca.«, Varaždinske vijesti, 8. prosinca 1993., br. 2552, 3.

48. Jasna TOMIČIĆ, »Kako (ni)su Varaždinski proslavili 700. godišnjicu«, Varaždinske vijesti, 5. ožujka 1981., br. 9, 8 .

49. (̌̌), »Prijedlog kulturnih potreba RSIZ-u«, Varaždinske vijesti, 27. lipnja 1985., br. 2110, 7. 


\section{SAŽETAK \\ RUDOLF HORVAT O SVOJEM RUKOPISU POVIJEST GRADA VARAŽDINA}

Najopsežnije i sigurno najcitiranije djelo o povijesti »grada baroka«, epitet je kojim se nesumnjivo može opisati Povijest grada Varaždina renomiranog hrvatskog povjesničara Rudolfa Horvata (Koprivnica, 14. ožujka 1873. - Zagreb, 25. svibnja 1947.). Njegovim se tiskom namjeravalo dostojno obilježiti proslavu jubileja sedamstogodišnjice grada Varaždina (1909.) - ali nije; rukopis je tiskan 1993. godine. Godine 2017. navršilo se sedam desetljeća od piščeve smrti, a 2018. godine, 125 godina od njegova rođenja i četvrt stoljeća od tiskanja povjesnice. Na temelju podacima obilne arhivske građe u varaždinskom i zagrebačkom arhivu, upotpunjuje se slika o njezinom nastanku. Iz sačuvanih točaka sjednica gradske vlasti, dopisa gradonačelnika i Prosvjetnog odbora, korespondencije između gradske vlasti i Horvata iščitava se napor autora u provođenju opsežnog istraživanja povijesti grada Varaždina i obradi građe za sastavljanje buduće povjesnice, njegovoj viziji o njezinom sadržaju i ustrajnosti $u$ isplati honorara koji je on neprestano smatrao primjerenim za svoj gotovo tridesetogodišnji rad. Također se iščitava napor njezinog naručitelja da primjerenu visinu honorara provjeri sa znanstvenim i nakladničkim institucijama, te je ugovori u skladu s tadašnjim lošim gospodarskim uvjetima. Naručitelj se o troškovima tiskanja buduće povjesnice raspitavao kod različitih tiskara unaprijed im poslavši predloške tiskanih historiografskih radova, pa tako i Horvatovog. U njezin nastanak uključivao je i mjerodavne osobe - zastupnike i ne-zastupnike grada Varaždina koji će na temelju svog stručnog iskustva i rada, putem triju višečlanih odbora donositi stručne zaključke o predanom rukopisu. Horvat je na njemu radio nepunih trideset godina. Zaključuje da je rukopis predao u dijelovima: u ožujku 1934., 1935., 1936., kolovozu 1938. i proljeće 1939. godine, izravno osobnim dolaskom u Varaždin ili posredstvom gradonačelnika Novakovića ili dragog mu prijatelja. Zaključuje se da je zamislio višedijelni sadržaj rukopisa: njegov I. dio, opća ili politička povijest tiskana je 1993. godine, a tematski II. dio sa zasebnim poglavljima ostao je neobjavljen; pod naslovom Dr. Rudolf Horvat: Kulturna povijest grada Varaždina, skupa s objavljenim prvim djelom, čuva se u Gradskom muzeju Varaždin. Želeći omogućiti Horvatu vrijeme za istraživanje i pisanje povjesnice, gradska vlast je uz pomoć tadašnjeg hrvatskog bana Pavla Raucha, piscu ishodila premještaj u tadašnji Zemaljski kraljevski arhiv u Zagrebu, kako bi tamo mogao istraživati sačuvanu arhivsku građu, a novčanom isplatom pripomogla njegova arhivska istraživanja u austrijskim i mađarskom arhivu i tisak studije Varaždin koncem 16. vijeka. U zagrebačkom arhivu Horvat je imao mogućnosti i vremena istraživati 
građu ne samo o povijesti Varaždina, nego i o povijesti drugih hrvatskih gradova, na temelju koje je također mogao raditi i na povjesnicama tih gradova. $\mathrm{U}$ tom se pogledu ističe i skroman doprinos varaždinskih gradskih zastupnika davne 1909. godine za hrvatsku historiografiju. U vezi s tim, s obzirom na to da je Horvat na rukopisu radio nepunih trideset godina i da ga je u dijelovima predao do 1939. godine, neminovno je uspoređivati rukopis i promatrati ga u kontekstu historiografskih radova nastalih tijekom 1930-ih godina.

Ključne riječi: Rudolf Horvat; Povijest grada Varaždina; rukopis; Varaždin; Stjepan Novaković; Krešimir Filić; varaždinska historiografija.

\section{SUMMARY \\ RUDOLF HORVAT ABOUT HIS MANUSCRIPT THE HISTORY OF THE TOWN OF VARAŽDIN}

The most comprehensive and most cited work on the history of "the Baroque Town" is undoubtedly the best description of The History of the Town of Varaždin by the renowned Croatian historian Rudolf Horvat (Koprivnica, 14 March 1873 - Zagreb, 25 May 1947). The manuscript was meant to be printed on the $700^{\text {th }}$ anniversary of the founding of the town of Varaždin (in 1909), but the plan failed; it was only printed in 1993. In 2017 it was seven decades since the author's death, and in 2018 we marked 125 years since his birth and a quarter of a century since the publishing of his historiographic work. With the help of rich and comprehensive archive material in State Archive in Varaždin and Croatian State Archives in Zagreb, we get the full picture about the making of his work. Reading the minutes from town assembly sessions, the letters by vice-mayor and Education board, and the correspondence between town officials and Horvat, we see how ardent the author was in conducting a comprehensive research of the history of Varaždin, in collecting the materials for the future historiographic work, in his vision regarding the work's content, and in his persistence in negotiating the fee he deemed reasonable for his 30-years effort. We can also see the commissioner's efforts to discuss the reasonable fee with scientific and publishing institutions, in order to agree a fee in accordance with the poor economic situation of that day and age; they negotiated the cost of printing of his future historiographic work with different printing offices having sent them similar examples of historiographic works, including Horvat's own. The commissioner was keen to involve other competent people in this process - representatives and non-representatives of the town assembly of Varaždin - who were supposed to use their professional 
and work experience and draw an expert conclusion about the manuscript by means of three multimembered committees. Horvat had worked on it for almost thirty years. He handed over his manuscript in parts in March 1934, 1935, 1936, August 1938 and in the Spring of 1939; he used to com to Varaždin in person or send the text via the mayor Novaković or one of his close friends. It is thought he planned to publish the manuscript in multiple volumes: the first part, general and political history, was published in 1993, whereas the topic-based, second part with separate chapters has never been published. This text titled Doctor Rudolf Horvat: The Cultural History of the Town of Varaždin, together with the published first part, is kept in the Varaždin City Museum. Wanting to give Horvat the time for research and writing of his historiographic work, the town authorities, with the help of the former governor of Croatia Ban Pavao Rauch, sent the author to the then Royal State Archive in Zagreb, where he studied archive materials, and helped him financially to continue his research in Austrian and Hungarian archives, as well as to publish the study Varaždin in the Late $16^{\text {th }}$ Century. In the Royal State Archive in Zagreb (today's Croatian State Archives), Horvat had the time and opportunity to research not only the history of Varaždin, but also the history of other Croatian towns, which allowed him to write historiographic works about these towns as well. That way the representatives of the Varaždin town assembly from 1909 made a small contribution to the development of historiography in Croatia. Regarding that and keeping in mind that Horvat worked on the manuscript for almost thirty years up until 1939, it is necessary to compare this manuscript in the context of historiographic works from the 1930s.

Key Words: Rudolf Horvat; The History of the Town of Varaždin; manuscript; Varaždin; Stjepan Novaković; Krešimir Filić; historiography of Varaždin. 